\title{
Maize polyamine oxidase in the presence of spermine/spermidine induces the apoptosis of LoVo human colon adenocarcinoma cells
}

\author{
SHINJI OHKUBO $^{1}$, ROMINA MANCINELLI ${ }^{2}$, SELENIA MIGLIETTA ${ }^{2}$, ALESSANDRA CONA $^{3}$, \\ RICCARDO ANGELINI ${ }^{3}$, GIANLUCA CANETTIERI ${ }^{4}$, DEMETRIOS A. SPANDIDOS ${ }^{5}$, \\ EUGENIO GAUDIO $^{2}$ and ENZO AGOSTINELLI ${ }^{1,6}$
}

\author{
${ }^{1}$ Department of Biochemical Sciences ‘A. Rossi Fanelli', Sapienza University of Rome, I-00185 Rome; \\ ${ }^{2}$ Department of Anatomical, Histological, Forensic Medicine and Orthopedics Sciences, Sapienza University of Rome, \\ I-00161 Rome; ${ }^{3}$ Department of Sciences, Roma Tre University, I-00146 Rome; ${ }^{4}$ Pasteur Laboratory, \\ Department of Molecular Medicine, Sapienza University of Rome, I-00161 Rome, Italy; \\ ${ }^{5}$ Laboratory of Clinical Virology, University of Crete School of Medicine, Heraklion 71003, Greece; \\ ${ }^{6}$ International Polyamines Foundation - ONLUS, I-00159 Rome, Italy
}

Received February 22, 2019; Accepted April 3, 2019

DOI: $10.3892 /$ ijo.2019.4780

\begin{abstract}
Amine oxidases, which contribute to the regulation of polyamine levels, catalyze the oxidative deamination of polyamines to generate $\mathrm{H}_{2} \mathrm{O}_{2}$ and aldehyde(s). In this study, and at least to the best of our knowledge, maize polyamine oxidase (ZmPAO) was used for the first time with the aim of identifying a novel strategy for cancer therapy. The cytotoxicity and the mechanisms of cell death induced by
\end{abstract}

Correspondence to: Professor Enzo Agostinelli, Department of Biochemical Sciences 'A. Rossi Fanelli', Sapienza University of Rome, Piazzale Aldo Moro 5, I-00185 Rome, Italy

E-mail: enzo.agostinelli@uniroma1.it; polyfoundation2017@gmail.com

Abbreviations: AAP, 4-aminoantipyrine; ALDH, aldehyde dehydrogenase; BSAO, bovine serum amine oxidase; DCHBS, 3,5-dichloro-2-hydroxybenzene-sulfonic acid; MDR, multidrug resistance; $\Delta \psi_{\mathrm{m}}$, mitochondrial membrane potential; P-gp, P-glycoprotein; PI, propidium iodide; SEM, scanning electron microscopy; TEM, transmission electron microscopy; ZmPAO, maize polyamine oxidase; JC-1, 5,5',6,6'-tetrachloro-1,1',3,3'-tetraethylimidacarbocyanine iodide; FAD, flavin-adenin-dinucleotide; GABA, $\gamma$-aminobutyric acid; ADR2, adriamycin; MDL 72527, N1,N4-bis(2,3butadienyl)-1,4-butanediamine dihydrochloride; $\mathrm{ED}_{50}$, effective dose 50; TPQ, 2,4,5-trihydroxyphenylalanine quinone; FBS, fetal bovine serum; HRP, horseradish peroxidase; MEM, minimum essential medium; BSA, bovine serum albumin; DOX, doxorubicin; EDTA, ethylenediaminetetraacetic acid; FITC, fluoresceine isothiocyanate conjugated; IU, international units; MFC, means fluorescence channel; PBS, phosphate-buffered saline; RNAse A, ribonuclease A; ROS, reactive oxygen species; SD, standard deviation; SDS/PAGE, sodium dodecyl sulphate/polyacrylamide gel electrophoresis; Spm, spermine; WT, wild-type; PEG, poly(ethylene glycol)

Key words: polyamines, polyamine oxidase, colon adenocarcinoma, apoptosis, multidrug resistance, mitochondrial membrane potential the enzymatic oxidation products of polyamine generated by $\mathrm{ZmPAO}$ were investigated. Exogenous spermine and $\mathrm{ZmPAO}$ treatment decreased cell viability in a spermine dose- and time-dependent manner, particularly, the viability of the multidrug-resistant (MDR) colon adenocarcinoma cells, LoVo DX, when compared with drug-sensitive ones (LoVo WT). Further analyses revealed that $\mathrm{H}_{2} \mathrm{O}_{2}$ derived from spermine was mainly responsible for the cytotoxicity. Flow cytometric analysis revealed that treatment with $\mathrm{ZmPAO}$ and spermine increased the apoptotic population of LoVo WT and LoVo DX cells. In addition, we found that treatment with $\mathrm{ZmPAO}$ and spermine markedly reduced mitochondrial membrane potential in the LoVo DX cells, in agreement with the results of cell viability and apoptosis assays. Transmission electron microscopic observations supported the involvement of mitochondrial depolarization in the apoptotic process. Therefore, the dysregulation of polyamine metabolism in tumor cells may be a potential therapeutic target. In addition, the development of MDR tumor cells is recognized as a major obstacle in cancer therapy. Therefore, the design of a novel therapeutic strategy based on the use of this combination may be taken into account, making this approach attractive mainly in treating MDR cancer patients.

\section{Introduction}

Polyamines are organic polycations implicated in several physiological functions, such as DNA synthesis, cellular proliferation, differentiation and the response to abiotic and biotic stresses (1-3). Several studies have emphasized the important activities displayed by polyamines. Among these, polyamines seem to play a role in the regulation of the translation elongation process by modulating the Ser/Thr kinases involved in the phosphorylation of translation elongation factors, in the regulation of ion channel gating and in the modulation of oxidative processes (4-8). In an interesting review, it was reported by Madeo et al (9) that the natural polyamine, spermidine, 
exerted prominent cardioprotective and neuroprotective effects, and prevented stem cell senescence. Moreover, spermidine displays other pleiotropic effects that include anti-inflammatory properties, antioxidant functions, the enhancement of mitochondrial metabolic function and respiration, as well as improved proteostasis and chaperone activity. A very recent study demonstrated a novel role of polyamines in the maintenance of genome integrity via homology-directed DNA repair (10). Therefore, naturally occurring polyamines, such as putrescine, spermidine and spermine are found in a wide variety of organisms from bacteria to plants and animals. Their levels are tightly regulated through several processes, including biosynthesis, catabolism, feedback regulation of expression and excretion from cells.

However, the dysregulation of polyamine metabolism is a frequent event in various pathological conditions, including cancer, inflammation, stroke, neurodegeneration, diabetes and renal failure $(11,12)$. In particular, high amounts of polyamines and polyamine biosynthesis enzymes are strongly associated with rapidly growing tumors, including breast, colon, prostate and gastric cancers $(13,14)$. Moreover, polyamines and their metabolites, such as diacetylated derivatives of spermine and spermidine, in urine and plasma, have also been considered as possible specific markers of neoplastic cell proliferation (15). Polyamines can regulate gene expression by altering the DNA and RNA structure. Several studies have demonstrated that polyamines also regulate oncogene expression and function through transcriptional and post-transcriptional processes (4,16-18). Given that cancer and polyamines appear to be tightly linked, the modulation of polyamine biosynthesis and catabolism has been considered as a promising target for both cancer chemoprevention and chemotherapy.

Polyamines are substrates of amine oxidases, a class of enzymes present in numerous living systems. These enzymes are important for the catabolism of polyamines. Enzymatic oxidation products of polyamines generated by amine oxidases, such as aldehyde(s) and $\mathrm{H}_{2} \mathrm{O}_{2}$, can induce several biological events.

Maize polyamine oxidase ( $\mathrm{ZmPAO}$ ), one of the best-characterized plant polyamine oxidases purified from maize, is a secretory glycoprotein with a non-covalently bound flavin-adenin-dinucleotide (FAD) as a cofactor in a ratio of 1 mol of FAD per mol of the enzyme $(19,20)$ (Table I). ZmPAO is an extracellular enzyme and is predominantly abundant in primary and secondary cell walls of several tissues (21). Several studies have suggested that ZmPAO activity is associated with cell wall stiffening and differentiation through the peroxidase-catalyzed cross-linking, and lignification of the cell wall (22-24). Not only that, since several lines of evidence suggest that $\mathrm{H}_{2} \mathrm{O}_{2}$ biosynthesis in the cell wall acts as a trigger to induce programmed cell death and cellular defense response (24), the accumulation of ZmPAO in the cell walls may be associated with the particular physiological event.

Amine oxidase from bovine serum (BSAO) is a $170 \mathrm{kDa}$ homodimeric glycoprotein, and each subunit contains a 2,4,5-trihydroxyphenylalanine quinone (TPQ) cofactor and a copper ion coordinated by three histidine residues. The primary amino group of the aminopropyl moiety, such as spermine, spermidine and benzylamine, are preferentially deaminated by bovine serum amine oxidase (BSAO) compared to putrescine $(25,26)$. BSAO catalyzes the oxidative deamination of spermine and spermidine with a 'ping-pong' mechanism, producing spermidine and putrescine, respectively, in addition to $\mathrm{H}_{2} \mathrm{O}_{2}$, ammonia, and corresponding aldehyde. Since the formed dialdehydes are unstable, they are likely to be converted to acrolein by spontaneous $\beta$-elimination $(27,28)$.

By contrast, ZmPAO oxidizes the $\mathrm{C}^{6}$ carbon on the endo side of the $\mathrm{N}^{5}$ nitrogens of spermine and spermidine, generating $\mathrm{N}$-(3-aminopropyl)-4-aminobutanal and 4-aminobutanal, respectively, in addition to 1,3-diaminopropane and $\mathrm{H}_{2} \mathrm{O}_{2}$ (29,30). $N$-(3-aminopropyl)-4-aminobutanal and 4-aminobutanal arising from polyamine oxidation spontaneously cyclize to form 1-(3-aminopropyl) pyrrolinium and 1-pyrroline, respectively (Fig. 1) (19,31). The former compound is mainly present in the bicyclic form of 1,5-diazabicyclo[4.3.0]nonane in the leaves of various cereals, and the latter can be further metabolized to $\gamma$-aminobutyric acid (GABA) by aldehyde dehydrogenase $(19,32,33)$. Oxidized polyamines are known to have toxic effects on a variety of bacteria and viruses. These aminoaldehyde(s) in mice have exhibited a consistent inhibitory effect on Leishmania infantum, the etiological agent of visceral leishmaniasis; in particular, 4-aminobutanal exhibited a lower $\mathrm{ED}_{50}$ value $(0.14 \mathrm{mg} / \mathrm{kg})$ than $N$-(3-aminopropyl)-4-aminobutanal (31). In vitro cultivation assays on Leishmania infantum promastigotes have also shown that the aminoaldehydes exert a significant inhibitory effect on the vitality and growth of these parasites (34).

Multidrug resistance/resistant (MDR) is the most commonly exploited mechanism through which cancer eludes chemotherapy and is crucial for cancer metastasis and recovery. MDR is defined as the resistance of the cancer cells to one chemotherapeutic drug accompanied by simultaneous resistance to a variety of structurally and mechanistically unrelated drugs $(35,36)$. MDR cancer cells exhibit a reduced intracellular accumulation of chemotherapeutic drugs by pumping them out of the cells. Resistance to chemotherapy and molecularly targeted therapies is a significant impediment to successful cancer treatment. Therefore, the search for an innovative therapeutic strategy against MDR tumors is ongoing.

Several in vitro studies have been performed to investigate whether the oxidative products of polyamines exert cytotoxic effects against human cancer cells. An MDR human colon adenocarcinoma cell line (LoVo DX), selected from the parental drug-sensitive cell line (LoVo WT) by continuous exposure to doxorubicin (DOX), has been shown to express high levels of membrane transporter protein P-glycoprotein (P-gp) which can transport chemotherapeutic drugs outside (37), suggesting that the resistance to anticancer agents in colon adenocarcinoma cells is attributed to overexpression of P-gp. Previous studies have shown that enzymatic oxidation products of exogenous spermine, catalyzed by BSAO, exert a greater cytotoxic effect on LoVo DX cells than on LoVo WT $(38,39)$. Other studies have demonstrated that human melanoma M14 MDR cells (M14 ADR2), overexpressing P-gp, as well as LoVo DX, are also more sensitive to spermine metabolites oxidized by BSAO than the parental M14 cells (M14 WT) (40-42). The antitumor efficacy of BSAO has also been evaluated in vivo. BSAO, immobilized on a poly(ethylene glycol) (PEG) biocompatible matrix, was previously directly injected into subcutaneous 
B16 melanoma tumors in C57BL mice, leading to decreased tumor growth $(43,44)$. Given that intratumor polyamine concentrations are increased in multiple tumors, these findings raise the possibility of using oxidation products of polyamines formed by amine oxidases to preferentially kill cancer cells and even MDR cancer cells.

Therefore, this study investigated the potential of ZmPAO to induce cancer cell death by the oxidative products of polyamines. ZmPAO was selected for use in this study due to its higher affinities and higher catalytic efficiencies for polyamine substrates than BSAO (45-48). Moreover, ZmPAO has a lower molecular weight $(53 \mathrm{kDa})$ than BSAO (170 kDa), which may be an advantage when the enzyme is conjugated to biocompatible carrier molecules for efficient delivery to tumor sites in vivo. Moreover, the expression system in the culture medium of Pichia pastoris for the production of recombinant ZmPAO, a monomeric enzyme, unlike BSAO that is a homodimeric enzyme, has been already established, which has shown high expression levels of recombinant ZmPAO (45). The catalytic parameters of the recombinant enzyme are similar to those of native enzyme (45). It seems easy to alter the DNA sequence to adapt the enzyme to drug delivery system or improve the enzyme features. In addition, $\mathrm{ZmPAO}$ is involved in the terminal polyamine catabolism that does not produce polyamines, while BSAO is implicated in a polyamine back-conversion pathway that converts spermine to spermidine, and then to putrescine $(25,29)$. ZmPAO delivery to the tumor microenvironment in vivo may cause polyamine depletion, leading to growth inhibition.

In this study, the involvement of $\mathrm{H}_{2} \mathrm{O}_{2}$ and aldehydes derived from spermine and spermidine oxidized by purified ZmPAO in causing cytotoxicity to LoVo WT and its MDR cells was investigated in vitro. It was also examined whether the cytotoxicity induced by the treatment with ZmPAO and spermine is associated with apoptosis. Moreover, the involvement of mitochondria in cell death induced by $\mathrm{ZmPAO} /$ spermine enzymatic systems was also assessed.

\section{Materials and methods}

Reagents. Spermine tetrahydrochloride and spermidine trihydrochloride were obtained from Fluka (Buchs, Switzerland). Fetal bovine serum (FBS), ribonuclease A (RNase A), catalase, 5,5',6,6'-tetrachloro-1,1',3,3'-tetraethyl-imidacarbocyanine iodide (JC-1), verapamil, bovine serum albumin (BSA), penicillin, streptomycin and propidium iodide (PI) were purchased from Sigma-Aldrich (St. Louis, MO, USA). Aldehyde dehydrogenase (ALDH) and $\mathrm{NAD}^{+}$were obtained from Boehringer-Mannheim (Mannheim, Germany). Commercial $\mathrm{H}_{2} \mathrm{O}_{2}$ was purchased from Baker Analyzed Reagent (J.T. Baker, Deventer, The Netherlands). The Annexin V-FITC apoptosis detection kit was obtained from Enzo Life Sciences (Farmingdale, NY, USA). Ham's F-12 medium was purchased from Gibco/Thermo Fischer Scientific (Waltham, MA, USA). All cell culture flasks and dishes were obtained from Corning (Corning, NY, USA).

Purification of ZmPAO and BSAO. ZmPAO was purified using SP-sepharose ion exchange chromatography from maize shoot grown in the dark at $25^{\circ} \mathrm{C}$ as described previously (49). The sample was concentrated by vacuum dialysis through a
Table I. Structural properties of ZmPAO and BSAO.

\begin{tabular}{lll}
\hline & \multicolumn{1}{c}{ ZmPAO } & \multicolumn{1}{c}{ BSAO } \\
\hline Source & Maize, cell wall & Calf, serum \\
Cofactor & FAD & $\mathrm{Cu}^{2+}, \mathrm{TPQ}$ \\
Molecular mass & $53 \mathrm{kDa}$ & $170 \mathrm{kDa}$ \\
Structure & $\begin{array}{l}\text { Monomeric } \\
\text { glycoprotein }\end{array}$ & $\begin{array}{l}\text { Homodimeric } \\
\text { glycoprotein }\end{array}$ \\
Catabolic pathway & $\begin{array}{l}\text { Terminal } \\
\text { polyamine } \\
\text { catabolism }\end{array}$ & $\begin{array}{l}\text { Back-conversion } \\
\text { pathway } \\
\text { catabolism }\end{array}$ \\
\hline
\end{tabular}

ZmPAO, maize polyamine oxidase; BSAO, bovine serum amine oxidase.

dialysis membrane with a $12-14,000$ Da cut-off, which was dialyzed against $50 \mathrm{mM}$ sodium phosphate buffer ( $\mathrm{pH}$ 5.3) for storage. BSAO was purified by a combination of ion-exchange and affinity chromatographies as previously described $(50,51)$. The BSAO purification factor was approximately 1,600-fold and a single band was obtained on 6\% SDS-PAGE gel. The protein concentrations for BSAO and ZmPAO were measured by the absorbance at 280 and $450 \mathrm{~nm}$ using an absorption extinction coefficient of 1.74 liters $\mathrm{g}^{-1} \mathrm{~cm}^{-1}$ and 0.213 liters $\mathrm{g}^{-1} \mathrm{~cm}^{-1}$, respectively. For all the experiments performed, $6.58 \times 10^{-3} \mathrm{U} / \mathrm{ml}$ of enzyme were used. The enzyme activity of BSAO was assayed as the amount of benzaldehyde formed per $\mathrm{min}(\mu \mathrm{mol} / \mathrm{min})$ from benzylamine at $250 \mathrm{~nm}$ $\left(\varepsilon=12,500 \mathrm{M}^{-1} \mathrm{~cm}^{-1}\right.$ ) in $0.1 \mathrm{M}$ sodium phosphate buffer $\left(\mathrm{pH}\right.$ 7.2) at $25^{\circ} \mathrm{C}$. 3,5-Dichloro-2-hydroxybenzene-sulfonic acid (DCHBS) is oxidized by horseradish peroxidase (HRP) in the presence of $\mathrm{H}_{2} \mathrm{O}_{2}$ to a semiquinone radical form, which generates a pink quinoneimine with 4-aminoantipyrine (AAP). For ZmPAO, the enzymatic activity was determined by measuring the accumulation of the pink quinononeimine dye $\left(\varepsilon_{515}=26,000 \mathrm{M}^{-1} \mathrm{~cm}^{-1}\right)$ produced from AAP and DCHBS in $0.1 \mathrm{M}$ sodium phosphate buffer $(\mathrm{pH} 7.4)$ at $25^{\circ} \mathrm{C}$, as previously described (52).

Determination of catalytic properties of ZmPAO and BSAO. The enzyme catalytic properties were spectrophotometrically determined by measuring the amount of $\mathrm{H}_{2} \mathrm{O}_{2}$ formed during the oxidation of the polyamines, spermine or spermidine. In the presence of AAP and DCHBS, the measurements were performed in $0.2 \mathrm{M}$ sodium phosphate buffer ( $\mathrm{pH}$ 6.0) at $25^{\circ} \mathrm{C}$ using spermine or spermidine as a substrate to detect ZmPAO activity, or in PBS (pH 7.4) at $37^{\circ} \mathrm{C}$ using spermine as a substrate for ZmPAO or BSAO activity. The pink adduct produced by the oxidation of both substrates was measured spectrophotometrically. The kinetic constants: Affinity constant $\left(K_{\mathrm{m}}\right)$, catalytic constant $\left(k_{\text {cat }}\right)$ and specificity constant $\left(k_{\text {cat }} / K_{\mathrm{m}}\right)$ values were calculated using Lineweaver-Burk plots for each enzyme.

Cell cultures. The LoVo cell line was isolated from a metastatic nodule by Dolfini et al (53); its MDR variant, 
LoVo DX, and a gastric adenocarcinoma cell line (AGS) were used in this study. The MDR cell line, LoVo DX, was obtained by the prolonged culture of drug-sensitive parental LoVo WT cells in medium containing DOX (Adriblastina; Pharmacia \& Upjohn, Milan, Italy) as previously described by Grandi et al (54). LoVo DX cells are also resistant to other drugs, such as etoposide and vincristine $(39,53)$. The LoVo cells were a kind gift from Professor E. Dolfini (University of Milan, Milan, Italy). The AGS cell line (homo sapiens gastric adenocarcinoma) was obtained from the American Type Culture Collection (ATCC ${ }^{\circledR}$ CRL-1739 ${ }^{\text {тм }}$; ATCC, Manassas, VA, USA). All cell lines were grown in Ham's F-12 medium containing L-glutamine supplemented with $10 \%$ FBS, $1 \%$ minimum essential medium (MEM) vitamins, $1 \%$ MEM non-essential amino acid, penicillin (100 U/ml) and streptomycin $(100 \mu \mathrm{g} / \mathrm{ml})$ and were incubated in a humidified atmosphere of $5 \% \mathrm{CO}_{2}$ in a water-jacketed incubator at $37^{\circ} \mathrm{C}$. For each passage, exponentially growing LoVo and AGS cells were harvested with $10 \mathrm{mM}$ EDTA in PBS and then by further addition of $0.25 \%$ trypsin solution in PBS. The trypsin activity was quenched by the addition of complete F-12 medium.

Cell viability assay. The cytotoxic effect induced by polyamine metabolites on human tumor cells was evaluated using a plating clonogenic assay. Cell viability assays were carried out using subconfluent cells that had been incubated in fresh medium for $24 \mathrm{~h}$ at $37^{\circ} \mathrm{C}$. Cells were detached with $10 \mathrm{mM}$ EDTA in PBS and then by addition of $0.25 \%$ trypsin in PBS. The harvested cells were washed with PBS containing $1 \%$ BSA (PBS-1\% BSA), centrifuged at $400 \mathrm{x}$ g for $2 \mathrm{~min}$ at $25^{\circ} \mathrm{C}$, and resuspended in PBS supplemented with $1 \%$ BSA. Freshly harvested cells $\left(10^{5} / \mathrm{ml}\right)$ were incubated at $37^{\circ} \mathrm{C}$ for different periods of time, up to $60 \mathrm{~min}$, in the presence of the following reagents, used alone or in combination: Several concentrations of polyamine, spermine or spermidine, BSAO or ZmPAO $\left(6.58 \times 10^{-3} \mathrm{U} / \mathrm{ml}\right)$, catalase $(242 \mathrm{U} / \mathrm{ml})$ from bovine liver, ALDH (EC 1.2.1.5) from yeast $(0.4 \mathrm{U} / \mathrm{ml})$ and $\mathrm{NAD}^{+}$ $(1.8 \mu \mathrm{g} / \mathrm{ml})$. Spermine and spermidine were freshly prepared prior to each experiment in water or phosphate buffer, respectively, and if present, added last, to initiate the enzymatic reaction. Following incubation at $37^{\circ} \mathrm{C}$ for different periods of time, up to $60 \mathrm{~min}$, cells were washed twice in PBS-1\% BSA, centrifuged at $400 \mathrm{x} \mathrm{g}$ for $2 \mathrm{~min}$ at $25^{\circ} \mathrm{C}$, and resuspended in $1 \mathrm{ml}$ PBS-1\% BSA. AGS, LoVo WT and LoVo DX cells were subsequently plated in tissue culture-coated Petri dishes and incubated at $37^{\circ} \mathrm{C}$ until colonies were formed (13 or 18 days, respectively). The colonies were washed with PBS, fixed with $70 \%$ ethanol, stained with methylene blue at $25^{\circ} \mathrm{C}$ for $5 \mathrm{~min}$ and counted manually. Control plating efficiencies were $>85 \%$ for the AGS and LoVo WT and $80 \%$ for the LoVo DX cells, corresponding to $9.1 \times 10^{4} \pm 1.0 \times 10^{4}$ and $8.5 \times 10^{4} \pm 1.0 \times 10^{4}$ number of cells, respectively. The percentage of colony-forming cells was determined as the ratio between the mean number of colonies in the treated and control samples.

Measurements 'in situ' of mitochondrial membrane potential $\left(\Delta \psi_{m}\right)$. The changes in $\Delta \psi_{\mathrm{m}}$ in the LoVo cells were assayed using the lipophilic cationic probe, JC-1 dye, as previously described (39). The LoVo WT and LoVo DX cells were harvested with EDTA/trypsin, washed with PBS-1\% BSA, centrifuged at $400 \times \mathrm{g}$ for $2 \mathrm{~min}$ at $25^{\circ} \mathrm{C}$, and resuspended in PBS-1\% BSA, as described above. The cells were treated with various concentrations of $\mathrm{H}_{2} \mathrm{O}_{2}$ or spermine in the presence of $\mathrm{ZmPAO}$ or $\mathrm{BSAO}$ for $1 \mathrm{~h}$ at $37^{\circ} \mathrm{C}$. Following $30 \mathrm{~min}$ of incubation at $37^{\circ} \mathrm{C}$, verapamil was further added to the solution at a final concentration of $100 \mu \mathrm{M}$, in order to inhibit the P-gp-mediated efflux of JC-1 in the LoVo DX cells. Exposure to verapamil significantly increased the fluorescence intensity of JC-1 in the LoVo DX cells, while it did not affect fluorescence in LoVo WT cells. Subsequently, the cells were stained with $2.5 \mu \mathrm{g} / \mathrm{ml}$ of JC-1 during the final $15 \mathrm{~min}$ of treatment at $37^{\circ} \mathrm{C}$. The detached cells were washed with cold PBS-1\% BSA and the cells were then resuspended in cold PBS. The samples were analyzed by a BD Accuri C6 flow cytometer (BD Biosciences, San Jose, CA, USA). JC-1 was excited using an argon laser at a wavelength of $488 \mathrm{~nm}$ (using a BD Accuri C6 flow cytometer). The emitted green (JC-1 monomer) and red (JC-1 aggregate) fluorescence were detected at the FL-1 channel $(533 / 30 \mathrm{~nm})$ and FL-2 channel (585/40 nm), respectively. At least 10,000 events/sample were acquired in log mode using an Accuri C6 flow cytometer. The ratio of red (FL2)/green (FL1) fluorescence intensity was used to represent the $\Delta \psi_{\mathrm{m}}$. As positive controls, LoVo WT and LoVo DX cells were treated with exogenous $\mathrm{H}_{2} \mathrm{O}_{2}$ solution for $60 \mathrm{~min}$ at $37^{\circ} \mathrm{C}$ and then labeled, as described above.

Determination of apoptotic cell death by Annexin V-FITC staining. To detect phosphatidylserine residue exposure on the surface of plasma membrane of tumor cells in the initial step of apoptosis, an Annexin V-FITC apoptosis detection kit was used as previously described by Van Engeland et al (55). LoVo WT and LoVo DX cells $\left(5 \times 10^{5} / \mathrm{ml}\right)$ were treated with several concentrations of spermine and $\mathrm{ZmPAO}$ for $1 \mathrm{~h}$ at $37^{\circ} \mathrm{C}$, as described above for cell viability assay. Cell suspensions were seeded in a 6 -well plate containing culture medium supplemented with FBS. Following incubation at $37^{\circ} \mathrm{C}$ for $48 \mathrm{~h}$, the cells were detached, washed with PBS, centrifuged at $400 \mathrm{x} \mathrm{g}$ for $2 \mathrm{~min}$ at $25^{\circ} \mathrm{C}$ and then stained with $1 \mu \mathrm{g} / \mathrm{ml}$ of Annexin V-FITC and with $1 \mu \mathrm{g} / \mathrm{ml}$ of PI for $10 \mathrm{~min}$ at room temperature in the dark. Annexin V-FITC and PI fluorescence were measured on the FL-1 channel (533/30 nm) and the FL-3 channel (>670 nm), respectively, with excitation at $488 \mathrm{~nm}$. A minimum of 10,000 events/sample was acquired.

Cell cycle analysis. Cell cycle distribution was analyzed by labeling the cells with PI. The assays were carried out as previously described by Nicoletti et al (56). Spermine- and ZmPAO-treated and untreated LoVo WT and LoVo DX cells $\left(5 \times 10^{5} / \mathrm{ml}\right)$, as described above in Annexin V-FITC labeling, were harvested, washed twice with cold PBS and centrifuged at $400 \mathrm{x} \mathrm{g}$ for $2 \mathrm{~min}$ at $4^{\circ} \mathrm{C}$. The pellet was fixed in $70 \%$ ethanol at $-20^{\circ} \mathrm{C}$ for $1 \mathrm{~h}$. After washing twice with PBS, the cells were resuspended in PBS containing $100 \mu \mathrm{g} / \mathrm{ml}$ RNase A and $40 \mu \mathrm{g} / \mathrm{ml}$ PI. Following incubation at $37^{\circ} \mathrm{C}$ for $1 \mathrm{~h}$, the cells were subsequently analyzed by flow cytometry using the FL-3 channel (>670 nm) with the acquisition of 10,000 events/sample.

Scanning and transmission electron microscopy analyses. Scanning electron microscopy (SEM) was performed to investigate the ultrastructural features of the cell surface. A 
Table II. Kinetic parameters of ZmPAO and BSAO.

\begin{tabular}{lcccccrr}
\hline Enzyme & Substrate & $\begin{array}{c}\mathrm{Tm} \\
\left({ }^{\circ} \mathrm{C}\right)\end{array}$ & $\mathrm{pH}$ & $\begin{array}{c}K_{\mathrm{m}} \\
(\mu \mathrm{M})\end{array}$ & $\begin{array}{c}\text { Specific activity } \\
(\mathrm{U} / \mathrm{mg} \text { pro. })\end{array}$ & $\begin{array}{r}k_{\text {cat }} \\
\left(\mathrm{S}^{-1}\right)\end{array}$ & $\begin{array}{r}k_{\text {cal }} / K_{\mathrm{m}} \\
\left(\mathrm{S}^{-1} \mu \mathrm{M}^{-1}\right)\end{array}$ \\
\hline ZmPAO & $\mathrm{SPM}$ & $25^{\circ} \mathrm{C}$ & 6.0 & 17.4 & 42.9 & 37.9 & 2.2 \\
ZmPAO & $\mathrm{SPD}$ & $25^{\circ} \mathrm{C}$ & 6.0 & 24.9 & 48.0 & 42.4 & 1.7 \\
ZmPAO & $\mathrm{SPM}$ & $37^{\circ} \mathrm{C}$ & 7.4 & 2.8 & 82.0 & 72.5 & 26.2 \\
BSAO & $\mathrm{SPM}$ & $37^{\circ} \mathrm{C}$ & 7.4 & 28.1 & 1.2 & 3.3 & 0.1 \\
\hline
\end{tabular}

$\mathrm{ZmPAO}$ was purified from maize as described in the Materials and methods. Kinetic data were obtained at 25 and $37^{\circ} \mathrm{C}$ at $\mathrm{pH} 6.0$ and 7.4 , respectively, in the presence of spermine or spermidine. $k_{\text {cat }}$ and $K_{\mathrm{m}}$ values were obtained using several concentrations of substrate, and determined from Lineweaver-Burk plots. ZmPAO, maize polyamine oxidase; BSAO, bovine serum amine oxidase; SPM, spermine; SPD, spermidine.

total of $3 \times 10^{5}$ cells were plated on glass coverslips contained in a 6-well plate and allowed to adhere overnight. The cells were grown to near confluence and in Ham's F-12 FBS-free medium containing $1 \%$ BSA, cells were incubated with $\mathrm{ZmPAO}$ and $18 \mu \mathrm{M}$ spermine, $18 \mu \mathrm{M} \mathrm{H}_{2} \mathrm{O}_{2}$, or only medium for $60 \mathrm{~min}$ at $37^{\circ} \mathrm{C}$. The cells were washed with F-12 medium and $0.1 \mathrm{M}$ cacodylate buffer and then fixed in $2.5 \%$ glutaraldehyde in $0.1 \mathrm{M}$ cacodylate buffer ( $\mathrm{pH} 7.3$ ), supplemented with $2 \%$ sucrose, at $4^{\circ} \mathrm{C}$ for $1 \mathrm{~h}$. The samples were rinsed in $0.1 \mathrm{M}$ cacodylate twice and then post-fixed with $1 \%$ osmium tetroxide $\left(\mathrm{OsO}_{4}\right)$ in $0.1 \mathrm{M}$ cacodylate buffer $(\mathrm{pH} 7.3)$ at room temperature for $30 \mathrm{~min}$. After washing in distilled water for $1 \mathrm{~h}$, the cells were dehydrated through graded ethanol concentrations (from $30 \%$ to absolute alcohol). The specimens were sputter-coated in a vacuum with an electrically conductive $5 \mathrm{~nm}$ thick layer of gold-palladium. Finally, the prepared samples were examined with a Hitachi S4000 field emission scanning electron microscope (Hitachi Ltd., Tokyo, Japan) operating at 6-8 kV a field emission scanning electron microscope.

For transmission electron microscopy (TEM) observation, LoVo WT and DX cells were harvested as described above. After washing with PBS-1\% BSA, the cells were incubated for $60 \mathrm{~min}$ at $37^{\circ} \mathrm{C}$ in the absence or presence of $21 \mu \mathrm{M}$ spermine, or $21 \mu \mathrm{M}$ of spermine and ZmPAO in Ham's F-12 FBS-free medium containing 1\% BSA. The cells were washed with F-12 medium twice and fixed in $2.5 \%$ glutaraldehyde in $0.1 \mathrm{M}$ cacodylate buffer ( $\mathrm{pH} 7.3$ ), added with $2 \%$ sucrose, at room temperature for $1 \mathrm{~h}$. The samples were washed with $0.1 \mathrm{M}$ cacodylate buffer twice, post-fixed with $1 \%$ osmium tetroxide $\left(\mathrm{OsO}_{4}\right)$ solution in $0.2 \mathrm{M}$ cacodylate buffer $(\mathrm{pH} 7.3)$ at room temperature for $2 \mathrm{~h}$ and rinsed in the same buffer. Cells were then embedded in small blocks of $1 \%$ agar of approximately $5 \times 5 \times 1 \mathrm{~mm}$ in size, dehydrated in ascending series of ethanol concentrations (from $30 \%$ to absolute alcohol), immersed in propylene oxide for solvent substitution, embedded in Epon 812 (Agar Scientific, Stansted, UK) and sectioned by a Reichert-Jung Ultracut E ultramicrotome. Semithin sections ( $1 \mu \mathrm{m}$ thick) were stained with Toluidine Blue, examined by light microscopy (Zeiss Axioskop) and photographed using a digital camera (Leica DFC230). Ultrathin sections (60-80 nm) were cut with a diamond knife, mounted on copper grids and contrasted with saturated uranyl acetate followed by lead citrate (SIC, Rome, Italy). They were examined and photographed using a Zeiss EM 10 and a Philips TEM CM100 Electron Microscopes operating at $80 \mathrm{kV}$ (FEI Co., Eindhoven, The Netherlands).
Statistical analysis. The data are presented as the means \pm SEM or means \pm SD. Statistical analysis was performed using one-way ANOVA with the Tukey's post hoc test in GraphPad Prism 8.0.2 (GraphPad Software). A P-value $<0.05$ was considered to indicate a statistically significant difference.

\section{Results}

Purification and characterization of $\mathrm{ZmPAO}$. ZmPAO purification was performed on 10-day-old maize seedlings. The kinetic parameters of the purified $\mathrm{ZmPAO}$ were determined and compared with those of BSAO, isolated from bovine plasma (Table II). ZmPAO exhibited similar $K_{\mathrm{m}}, k_{\text {cat }}$ and $k_{\text {cat }} / K_{\mathrm{m}}$ values for both substrates, spermine and spermidine, at $25^{\circ} \mathrm{C}$ and $\mathrm{pH}$ 6.0. The $K_{\mathrm{m}}$ value for the oxidation of spermine by ZmPAO decreased from $17.4 \mu \mathrm{M}$ at $25^{\circ} \mathrm{C}$ and $\mathrm{pH} 6.0$ to $2.8 \mu \mathrm{M}$ at $37^{\circ} \mathrm{C}$ and $\mathrm{pH} 7.4$. The $k_{\text {cat }}$ and $k_{\mathrm{cat}} / K_{\mathrm{m}}$ values increased from $37.9 \mathrm{~S}^{-1}$ and $2.2 \mathrm{~S}^{-1} \mu \mathrm{M}^{-1}$ measured at $25^{\circ} \mathrm{C}$ and $\mathrm{pH} 6.0$ to $72.5 \mathrm{~S}^{-1}$ and $26.2 \mathrm{~S}^{-1} \mu \mathrm{M}^{-1}$ determined at $37^{\circ} \mathrm{C}$ and $\mathrm{pH} 7.4$, respectively. The enzyme exhibited a higher affinity for spermine than BSAO at $37^{\circ} \mathrm{C}$ and $\mathrm{pH}$ 7.4. The affinity of ZmPAO was approximately 10-fold greater than that of BSAO $(2.8$ vs. $28.1 \mu \mathrm{M})$ and the specificity constant of $\mathrm{ZmPAO}$ was $>200$-fold higher than that of $\operatorname{BSAO}\left(26.2 \mathrm{~S}^{-1} \mu \mathrm{M}^{-1}\right.$ vs. $\left.0.1 \mathrm{~S}^{-1} \mu \mathrm{M}^{-1}\right)$.

Cytotoxic effect induced by ZmPAO in the presence of polyamine on human tumor cell cultures. The cytotoxic effect caused by the oxidation products of polyamines, spermine and spermidine, generated by the enzymatic reaction catalyzed by ZmPAO (Fig. 1) was examined on LoVo WT and LoVo DX cells. The cells were treated with various concentrations of spermine or spermidine in presence of $\mathrm{ZmPAO}$ for $1 \mathrm{~h}$ at $37^{\circ} \mathrm{C}$. A clonogenic assay revealed that the viability of the LoVo WT and LoVo DX cells gradually decreased with the polyamine concentration of up to $15 \mu \mathrm{M}$ (Fig. 2). It was also observed that the treatments significantly reduced the viability of the LoVo DX cells when compared with the LoVo WT ones. $\mathrm{ZmPAO}$ catalyzes the conversion of spermine and spermidine to $\mathrm{N}$-(3-aminopropyl)-4-aminobutanal and 4-aminobutanal, respectively, in addition to the formation of $\mathrm{H}_{2} \mathrm{O}_{2}$ and 1,3-diaminopropane. No significant differences in the viability of the cells treated with spermine and those treated in the presence of spermidine were observed between the LoVo WT and LoVo DX cell lines (Fig. 2). Likewise, in the human gastric cancer cell line, AGS, treatment with each polyamine 

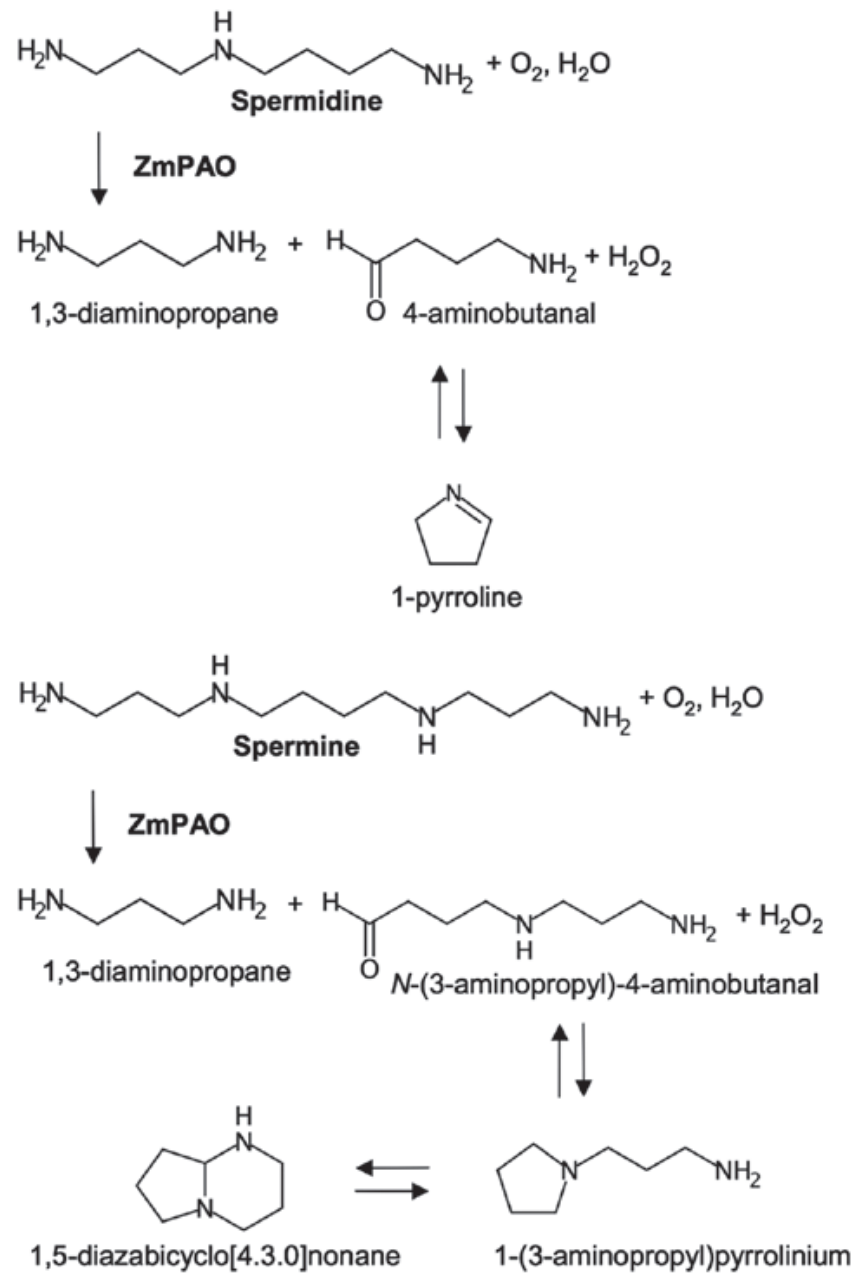

Figure 1. Schematic of spermidine and spermine oxidation catalyzed by ZmPAO. ZmPAO, maize polyamine oxidase.

in the presence of $\mathrm{ZmPAO}\left(6.58 \times 10^{-3} \mathrm{U} / \mathrm{ml}\right)$ was effective in inhibiting cell growth in a dose-dependent manner and the cell survival rates were nearly the same for both the treatments (data not shown). This suggested that either the cytotoxicity induced by the treatments was mainly due to $\mathrm{H}_{2} \mathrm{O}_{2}$, or both aldehydes produced by the enzymatic reactions could provoke the same level of cytotoxicity.

To determine the cytotoxic effect caused by $\mathrm{H}_{2} \mathrm{O}_{2}$ and aldehydes formed from spermine, the LoVo cells were treated with spermine and $\mathrm{ZmPAO}$ in the presence of the scavengers, catalase and ALDH. Both the LoVo WT and LoVo DX cells treated with $12 \mu \mathrm{M}$ of exogenous spermine and ZmPAO exhibited a cytotoxic effect in a time-dependent manner. The cytotoxicity was completely prevented by the addition of catalase, while it was not affected by the presence of ALDH (Fig. 3). These results demonstrated that the aldehyde produced from spermine was not responsible for the cytotoxicity. The cytotoxicity induced by $\mathrm{ZmPAO}$ and exogenous spermidine was also completely inhibited in the presence of catalase in both the LoVo WT and LoVo DX cells (data not shown), suggesting that under these experimental conditions, the cytotoxicity was only due to $\mathrm{H}_{2} \mathrm{O}_{2}$.

To further assess the cytotoxicity of polyamine metabolites, $\mathrm{H}_{2} \mathrm{O}_{2}$ and aldehydes, the LoVo cells were treated with increasing concentrations of exogenous $\mathrm{H}_{2} \mathrm{O}_{2}$ or spermine and the $\mathrm{ZmPAO}$ enzymatic system for $60 \mathrm{~min}$. The results of

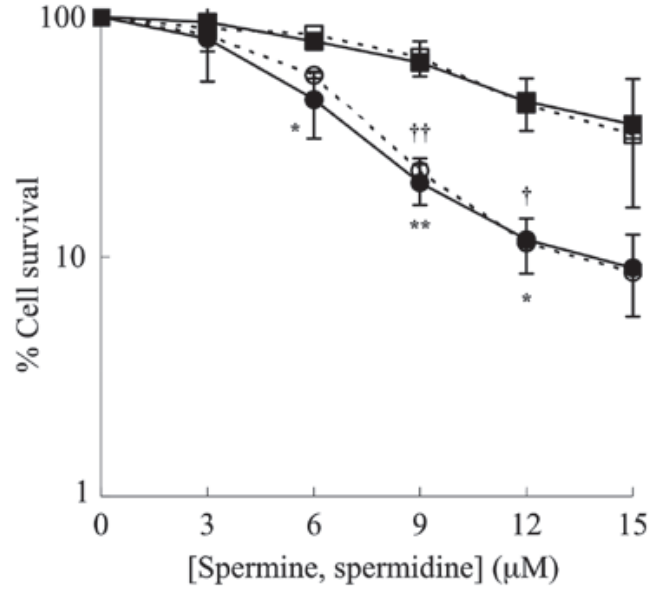

Figure 2. Effects of exogenous spermine and spermidine concentrations on percentage cell survival in the presence of purified ZmPAO in LoVo cells. LoVo WT (squares) and LoVo DX (circles) cells were incubated with ZmPAO in the presence of various concentrations of either spermine (solid symbols) or spermidine (open symbols) for $60 \mathrm{~min}$ at $37^{\circ} \mathrm{C}$. The percentage of cell survival was determined using a clonogenic assay. Each point represents the mean \pm SEM of 2 independent experiments, with 2 to 5 plates per experiment. Where not shown, error bars lie within the symbols. Data are shown on a logarithmic scale. Data were analyzed by one-way ANOVA, followed by Tukey's post hoc test. ${ }^{*} \mathrm{P}<0.05$ and ${ }^{* *} \mathrm{P}<0.01$ vs. LoVo WT cells incubated with $\mathrm{ZmPAO}$ and spermine; ${ }^{\dagger} \mathrm{P}<0.05$ and ${ }^{\dagger} \mathrm{P}<0.01$ vs. LoVo WT cells incubated with $\mathrm{ZmPAO}$ and spermidine. ZmPAO, maize polyamine oxidase; LoVo WT cells, LoVo wild-type cells; LoVo DX cells, LoVo multidrug-resistant cells.

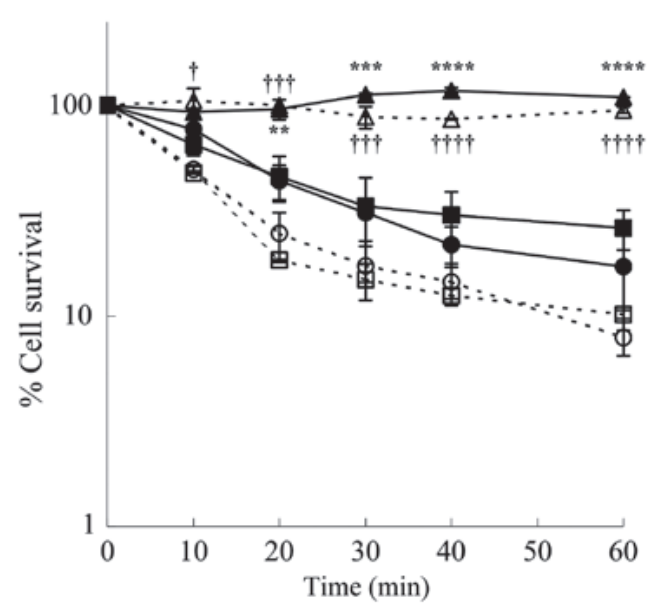

Figure 3. Effects of both catalase and ALDH on cytotoxicity induced on LoVo cells by purified ZmPAO in the presence of spermine. LoVo WT (solid symbols) and LoVo DX (open symbols) cells were incubated with $\mathrm{ZmPAO}$ and $12 \mu \mathrm{M}$ of exogenous spermine up to $60 \mathrm{~min}$ at $37^{\circ} \mathrm{C}$, in the absence (squares) or presence of $240 \mathrm{U} / \mathrm{ml}$ catalase (triangles) or $0.4 \mathrm{U} / \mathrm{ml} \mathrm{ALDH}$ and $1.8 \mathrm{mg} / \mathrm{ml}$ $\mathrm{NAD}^{+}$(circles). Each point represents the mean \pm SEM of 2 independent experiments, with 2 to 5 plates per experiment. Where not shown, error bars lie within symbols. Data are shown on a logarithmic scale. Data were analyzed by one-way ANOVA, followed by Tukey's post hoc test. ${ }^{* *} \mathrm{P}<0.01$, ${ }^{* * * *} \mathrm{P}<0.001$ and ${ }^{* * * *} \mathrm{P}<0.0001$ vs. LoVo WT cells incubated with ZmPAO and spermine; ${ }^{\dagger} \mathrm{P}<0.05,{ }^{\dagger \dagger} \mathrm{P}<0.001$ and ${ }^{\dagger \dagger \dagger} \mathrm{P}<0.0001$ vs. LoVo DX cells incubated with ZmPAO and spermine. ZmPAO, maize polyamine oxidase; LoVo WT cells, LoVo wild-type cells; LoVo DX cells, LoVo multidrug-resistant cells.

clonogenic assay revealed that in both cell lines, exogenous $\mathrm{H}_{2} \mathrm{O}_{2}$ exerted a slightly greater cytotoxicity than the same molar concentration of exogenous spermine enzymatically oxidized by ZmPAO (Fig. 4). Treatment of the LoVo WT and LoVo DX cells with $15 \mu \mathrm{M}$ of $\mathrm{H}_{2} \mathrm{O}_{2}$ at $37^{\circ} \mathrm{C}$ for $60 \mathrm{~min}$ 


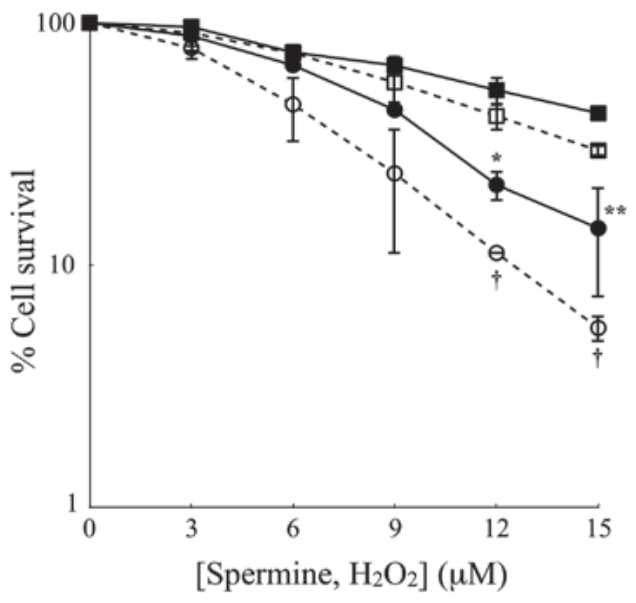

Figure 4. Effects of exogenous hydrogen peroxide on LoVo cell viability in comparison with the effects induced by purified $\mathrm{ZmPAO}$ and spermine. LoVo WT (squares) and LoVo DX (circles) cells were incubated with various concentrations of either exogenous hydrogen peroxide (open symbols) or exogenous spermine plus $\mathrm{ZmPAO}$ (solid symbols) for $60 \mathrm{~min}$ at $37^{\circ} \mathrm{C}$. Each point represents the means \pm SEM of 2 independent experiments, with 2 to 5 plates per experiment. Where not shown, error bars lie within symbols. Data are shown on a logarithmic scale. Data were analyzed by one-way ANOVA, followed by Tukey's post hoc test. " $\mathrm{P}<0.05$ and ${ }^{* *} \mathrm{P}<0.01$ vs. LoVo WT cells incubated with $\mathrm{ZmPAO}$ and spermine; ${ }^{\circ} \mathrm{P}<0.05$ vs. LoVo WT cells incubated with $\mathrm{H}_{2} \mathrm{O}_{2}$. ZmPAO, maize polyamine oxidase; LoVo WT cells, LoVo wild-type cells; LoVo DX cells, LoVo multidrug-resistant cells.

decreased the viability to 29.7 and $5.5 \%$, respectively, while the exposure of both cell lines to the same molar concentration of spermine in the presence of $\mathrm{ZmPAO}$ reduced the viability to 42.4 and $14.2 \%$, respectively (Fig. 4).

Comparison of cytotoxicity to LoVo cells induced by ZmPAO and BSAO in the presence of exogenous spermine. The cytotoxic effects of spermine metabolites generated by ZmPAO were compared with those induced by BSAO on the LoVo cells. As shown in Fig. 5, the viability of the LoVo WT and LoVo DX cells incubated up to $60 \mathrm{~min}$ at $37^{\circ} \mathrm{C}$ in the presence of $12 \mu \mathrm{M}$ spermine and $\mathrm{ZmPAO}$ or $\mathrm{BSAO}$ was examined. The metabolites formed by $\mathrm{BSAO} /$ spermine enzymatic system induced a more significant cytotoxicity than that produced by $\mathrm{ZmPAO} /$ spermine during the whole duration of the incubation period. After $60 \mathrm{~min}$ of incubation, treatment with ZmPAO and $\mathrm{BSAO}$ in the presence of spermine reduced the viability of the LoVo WT cells to 39.1 and 5.3\%, respectively. The LoVo DX cells were found to be more sensitive to the treatment in the presence of both enzymes. The viability of the LoVo DX cells treated with $\mathrm{ZmPAO}$ and $\mathrm{BSAO}$ in the presence of spermine decreased to 15.1 and $0.4 \%$, respectively.

Analysis of apoptosis induction by flow cytometry. The loss of phospholipid asymmetry and the appearance of phosphatidylserine residues on the outer layer of the plasma membrane is an early signal of cell death, namely apoptosis. Annexin $\mathrm{V}$ is a $\mathrm{Ca}^{2+}$-dependent phospholipid-binding protein with a high affinity for phosphatidylserine. In this study, to detect externalized phosphatidylserine, Annexin V-FITC/PI staining was performed in the LoVo WT and LoVo DX cells. The results of flow cytometric analysis are shown in Fig. 6. Treatment with 12 and $24 \mu \mathrm{M}$ of exogenous spermine in the

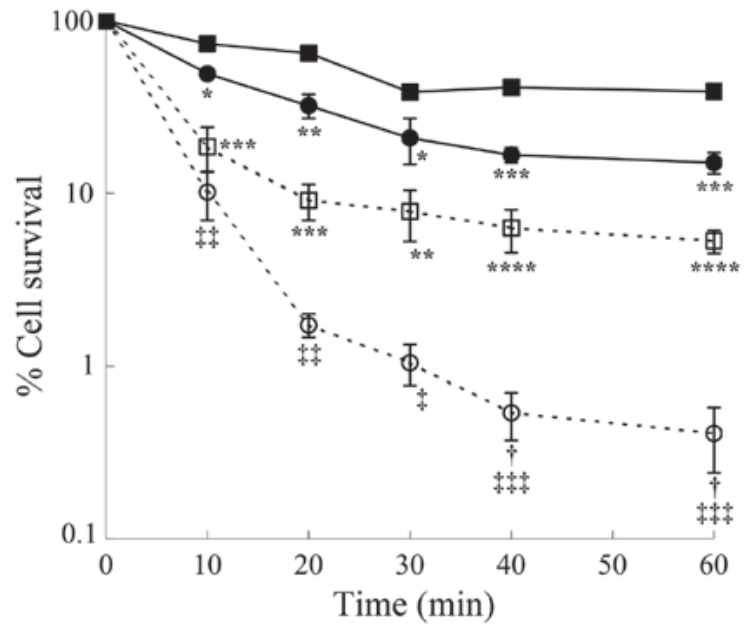

Figure 5. Comparison of cytotoxic effects induced by both purified ZmPAO and BSAO in the presence of spermine on LoVo cells. LoVo WT (squares) and LoVo DX (circles) cells were incubated with ZmPAO (solid symbols) or BSAO (open symbols) in the presence of $12 \mu \mathrm{M}$ spermine up to $60 \mathrm{~min}$ at $37^{\circ} \mathrm{C}$. Each point represents the mean \pm SEM of 2 independent experiments, with 2 to 5 plates per experiment. Where not visible, error bars are smaller than the symbols. Data are shown on a logarithmic scale. Data were analyzed by one-way ANOVA, followed by Tukey's post hoc test. ${ }^{*} \mathrm{P}<0.05,{ }^{* *} \mathrm{P}<0.01$, ${ }^{* * * *} \mathrm{P}<0.001$ and ${ }^{* * * *} \mathrm{P}<0.0001$ vs. LoVo WT cells incubated with ZmPAO and spermine; ${ }^{\dagger} \mathrm{P}<0.05$ vs. LoVo WT cells incubated with BSAO and spermine; ${ }^{+} \mathrm{P}<0.05,{ }^{*} \mathrm{P}<0.01$ and ${ }^{+*} \mathrm{P}<0.001$ vs. LoVo DX cells incubated with ZmPAO and spermine. ZmPAO, maize polyamine oxidase; BSAO, bovine serum amine oxidase; LoVo WT cells, LoVo wild-type cells; LoVo DX cells, LoVo multidrug-resistant cells.

presence of purified $\mathrm{ZmPAO}$ increased the percentage of the total apoptotic cells (Fig. 6A, lower and upper right quadrants) to 26.0 and $42.3 \%$, respectively, compared with the untreated LoVo WT cells (8.7\%) (Fig. 6A, left panels). On the contrary, the percentage of apoptotic cells was higher in the LoVo DX cells than the LoVo WT cells following treatment with 12 and $24 \mu \mathrm{M}$ of exogenous spermine (Fig. 6A, right panels, 49.2 and 57.6\%, respectively, and Fig. 6B). An increase in the number of apoptotic cells following treatment was also detectable in the AGS cells, resulting in 32.2 and $58.0 \%$ Annexin V-positive cells in the treated cells with 24 and $48 \mu \mathrm{M}$ of spermine in the presence of $\mathrm{ZmPAO}$, respectively (data not shown).

To confirm the involvement of apoptotic cell death induced by $\mathrm{ZmPAO} /$ spermine, flow cytometric analysis using PI staining was performed to analyze the cell cycle status. The apoptotic cells that undergo DNA fragmentation exhibit sub-G1 DNA contents. Exposure of the LoVo WT and DX cells to exogenous spermine and $\mathrm{ZmPAO}$ induced a significant increase in the sub-G1 apoptotic cell population, compared to that observed in the untreated control cells (Fig. 7). The percentage of treated LoVo DX cells in the sub-G1 phase was higher than the percentage of LoVo WT cells in the same phase, which is consistent with the results of the Annexin V-FITC/PI staining assay (Fig. 6). These results confirm the cytotoxicity induced by spermine enzymatic oxidation products and suggest the involvement of an apoptotic mechanism.

Morphological and ultrastructural changes observed by SEM and TEM analyses. To further investigate the mechanisms underlying spermine metabolite-mediated cytotoxicity, the morphological changes and the ultrastructural modifications 
A

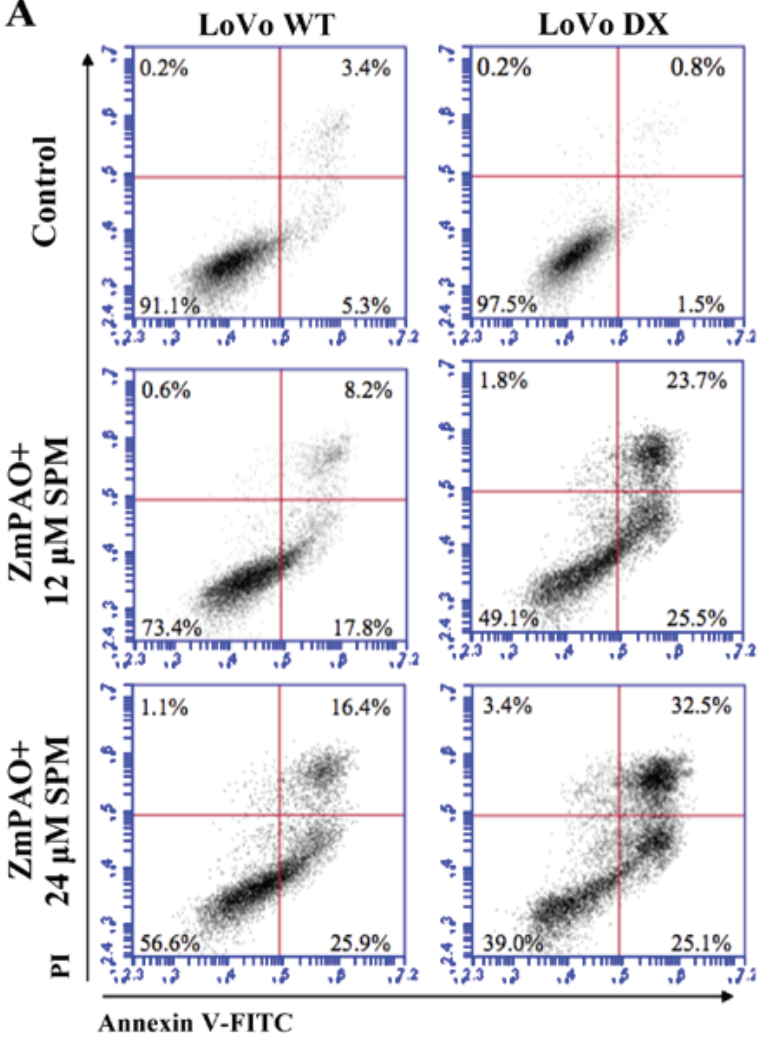

B

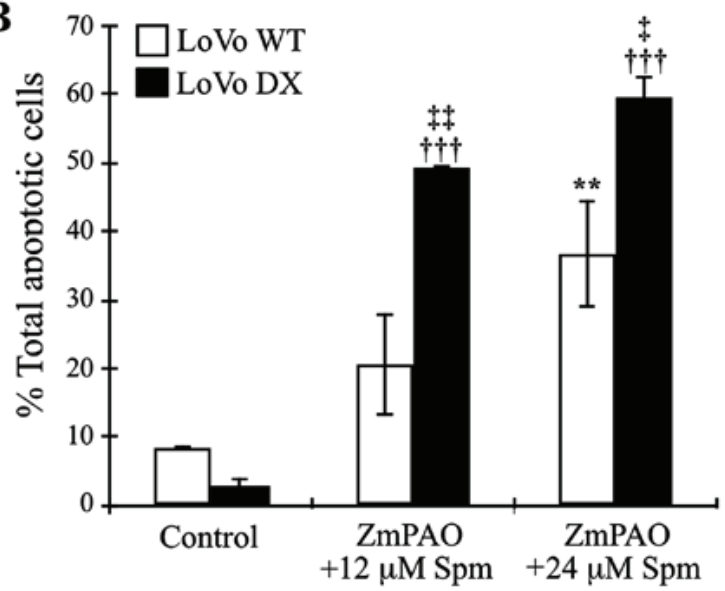

Figure 6. Flow cytometric analysis of apoptosis of LoVo cells after double labeling with Annexin V-FITC and PI. LoVo cells were incubated with 12 or $24 \mu \mathrm{M}$ spermine in the presence of $\mathrm{ZmPAO}$ for $60 \mathrm{~min}$ at $37^{\circ} \mathrm{C}$. At $24 \mathrm{~h}$ after the end of the treatment, and incubation at $37^{\circ} \mathrm{C}$, cells were analyzed by flow cytometry. (A) Representative Annexin V-FITC and PI flow cytometry dot plots of LoVo WT and LoVo DX are shown. The $\mathrm{x}$-axis represents FITC staining, and the $\mathrm{y}$-axis represents PI staining. The percentage of cells displaying Annexin V-FITC positive/PI-negative (early apoptosis), Annexin V-FITC positive/PI-positive (late apoptosis or dead), Annexin V-FITC negative/PI-positive (necrosis) and double negative cells (viable cells) is indicated. The dot plots have been obtained from 1 out of 2 independent experiments, performed in the same experimental conditions, which gave similar results. (B) Each bar represents the mean $\pm \mathrm{SD}$ of total apoptotic cells of 2 independent experiments. Data were analyzed by one-way ANOVA, followed by Tukey's post hoc test. ${ }^{* *} \mathrm{P}<0.01$ vs. control LoVo WT cells; ${ }^{\dagger} \mathrm{P}<0.001$ vs. control LoVo DX cells; ${ }^{\dagger} \mathrm{P}<0.05$ and P $<0.01$ vs. LoVo WT cells incubated with ZmPAO and spermine. ZmPAO, maize polyamine oxidase; LoVo WT cells, LoVo wild-type cells; LoVo DX cells, LoVo multidrug-resistant cells.

induced by treatment of the LoVo cells with ZmPAO and spermine were examined by SEM and TEM. The LoVo WT
A
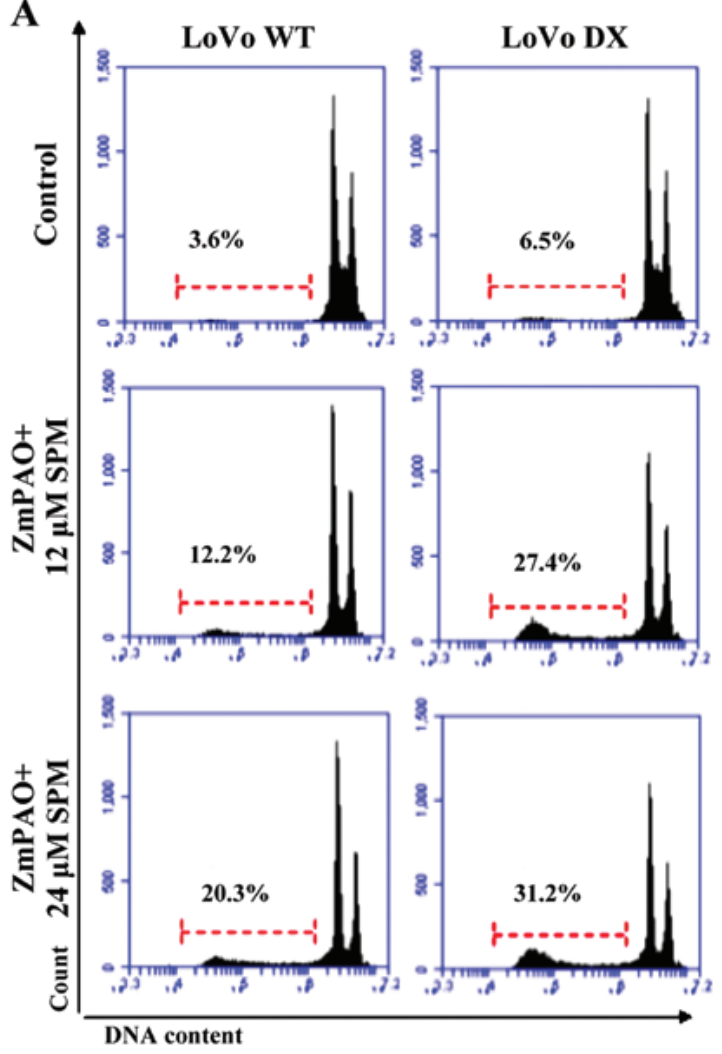

B

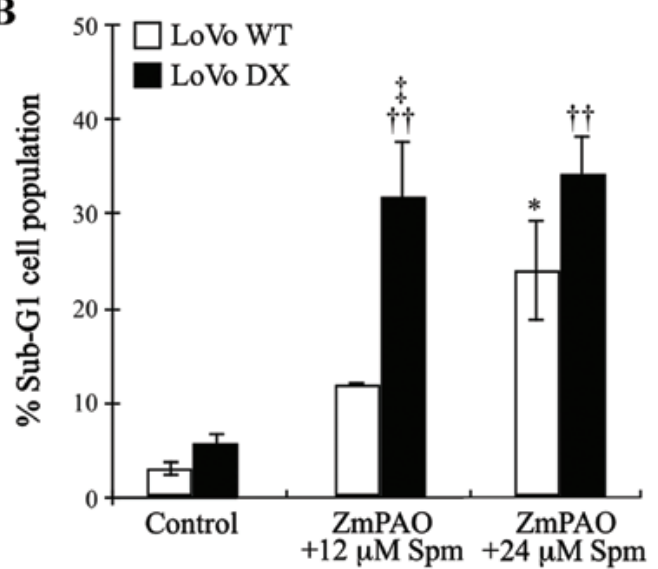

Figure 7. Cell cycle analysis carried out by flow cytometry on LoVo cells. LoVo cells were treated with 12 or $24 \mu \mathrm{M}$ spermine in the presence of $\mathrm{ZmPAO}$ for $60 \mathrm{~min}$ at $37^{\circ} \mathrm{C}$. At $24 \mathrm{~h}$ after the end of the treatment, and incubation at $37^{\circ} \mathrm{C}$, followed by the staining with PI, the cells were analyzed by flow cytometry. (A) Representative histograms of sub-G1 analysis performed on LoVo WT and LoVo DX cells using PI staining are shown. The percentage of the sub-G1 cell population is indicated. The histograms have been obtained from 1 out of 2 experiments carried out in the same experimental conditions, which gave similar results. (B) Each bar represents the mean \pm SD of sub-G1 cell population of 2 independent experiments. Data were analyzed by one-way ANOVA, followed by Tukey's post hoc test. " $\mathrm{P}<0.05$ vs. control LoVo WT cells; ${ }^{\dagger} \mathrm{P}<0.01$ vs. control LoVo DX cells; ${ }^{\dagger} \mathrm{P}<0.05$ vs. LoVo WT cells incubated with $\mathrm{ZmPAO}$ and spermine. ZmPAO, maize polyamine oxidase; LoVo WT cells, LoVo wild-type cells; LoVo DX cells, LoVo multidrug-resistant cells.

and LoVo DX control cells exhibited numerous randomly distributed microvilli (Fig. 8A and D). In particular, the LoVo WT control cells exhibited a typical polygonal shape (Fig. 8A). Treatment with spermine alone $18 \mu \mathrm{M}$ did not affect the morphological aspect of either the LoVo WT or 

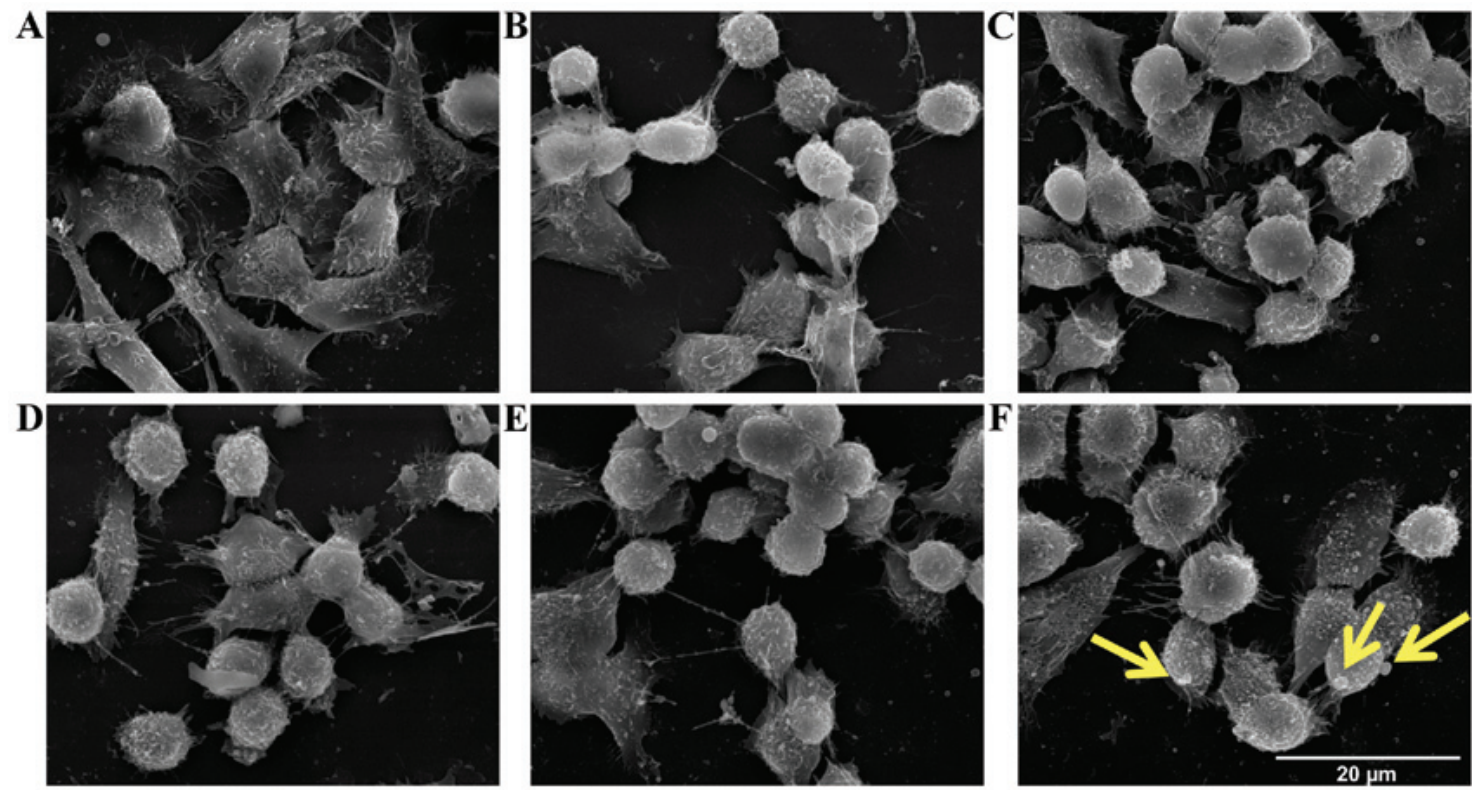

Figure 8. Effects of exposure of LoVo WT and LoVo DX cells to ZmPAO and spermine on the morphology observed by scanning electron microscopy (SEM). (A-C) LoVo WT and (D-F) LoVo DX cells were incubated at $37^{\circ} \mathrm{C}$ for $60 \mathrm{~min}$; (A and D) untreated cells; (B and E) cells treated with $18 \mu \mathrm{M} \mathrm{H} \mathrm{H}_{2}$ alone; (C and F) cells treated with ZmPAO and $18 \mu \mathrm{M}$ spermine. Scale bars, $20 \mu \mathrm{m}$. ZmPAO, maize polyamine oxidase; LoVo WT cells, LoVo wild-type cells; LoVo DX cells, LoVo multidrug-resistant cells.
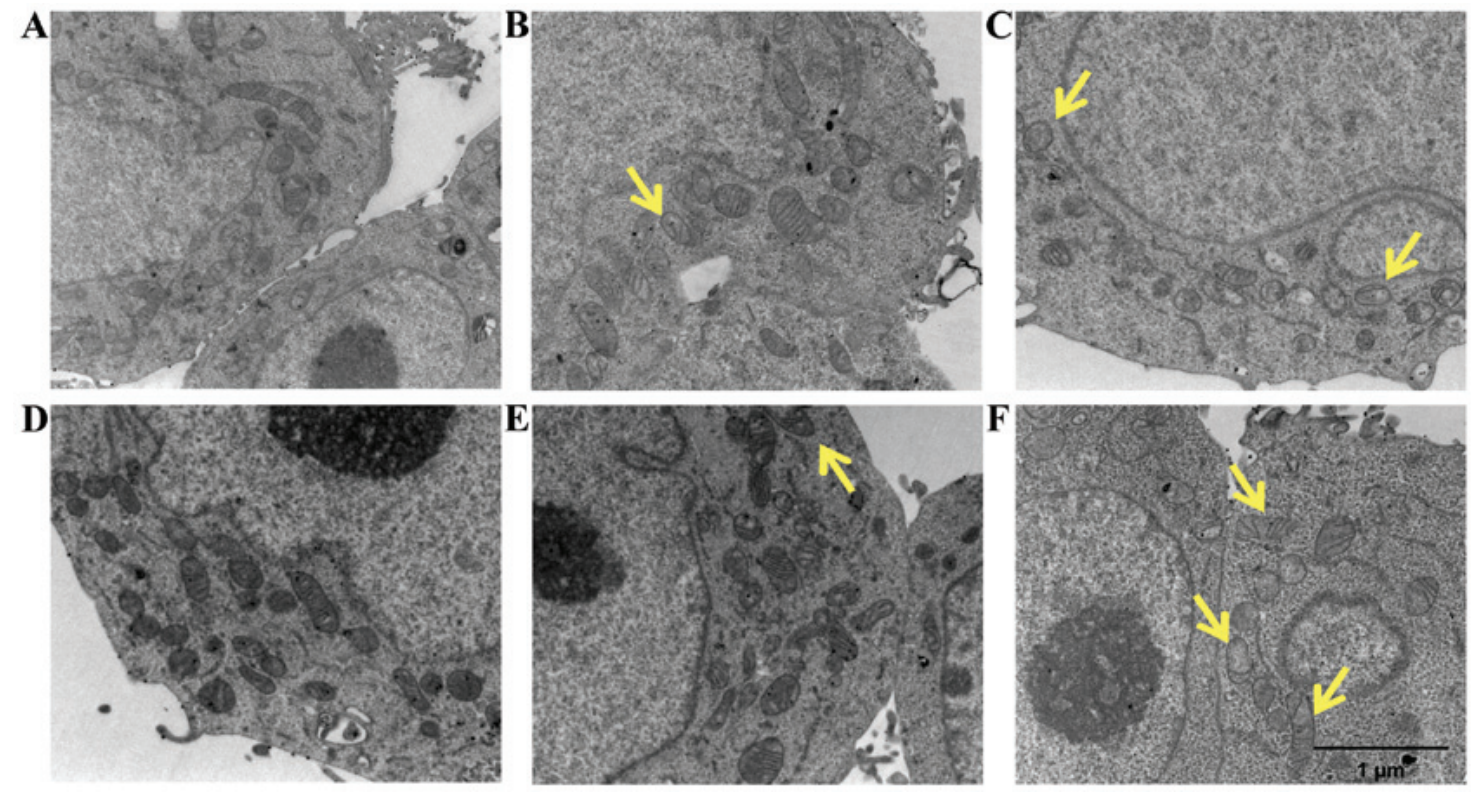

Figure 9. Transmission electron microscopic observations (TEM) of LoVo WT and LoVo DX cells. (A-C) LoVo WT and (D-F) LoVo DX cells were incubated at $37^{\circ} \mathrm{C}$ for $60 \mathrm{~min}$. (A and D) Untreated cells; (B and E) cells treated with $21 \mu \mathrm{M}$ spermine alone; (C and F) cells treated with ZmPAO and $21 \mu \mathrm{M}$ spermine. Scale bars, $1 \mu \mathrm{m}$. ZmPAO, maize polyamine oxidase; LoVo WT cells, LoVo wild-type cells; LoVo DX cells, LoVo multidrug-resistant cells.

LoVo DX cells (data not shown). Following incubation with exogenous $\mathrm{H}_{2} \mathrm{O}_{2}$ or $\mathrm{ZmPAO}$ and spermine, rounded cells were observed in the LoVo WT cells (Fig. 8B and C). The LoVo DX cells appeared to be affected by treatment with $18 \mu \mathrm{M} \mathrm{H}_{2} \mathrm{O}_{2}$ alone (Fig. 8E) and, in particular, following treatment with $\mathrm{ZmPAO}$ and spermine, morphological alterations were more evident, in that tiny blebs appeared on the surface and numerous cells tended to detach from the substrate (Fig. 8F). Analyses by TEM were also performed to clarify which subcellular organelles are the targets involved during the treatment. Both the LoVo WT and LoVo DX cells which were left untreated exhibited a well-preserved ultrastructure of cytoplasmic organelles and mitochondria (Fig. 9A and D). Treatment with spermine alone did not induce any consistent ultrastructural changes in both cell lines (Fig. 9B and E). By contrast, following treatment with $\mathrm{ZmPAO}$ and spermine, the LoVo WT cells exhibited mitochondrial alterations, which were considered to be a typical ultrastructural feature of apoptosis (Fig. 9C). Moreover, treatment with the enzymatic system induced marked mitochondrial alterations in the LoVo DX cells (Fig. 9F). Almost all mitochondria possessed abnormal vacuolated cristae. 
A
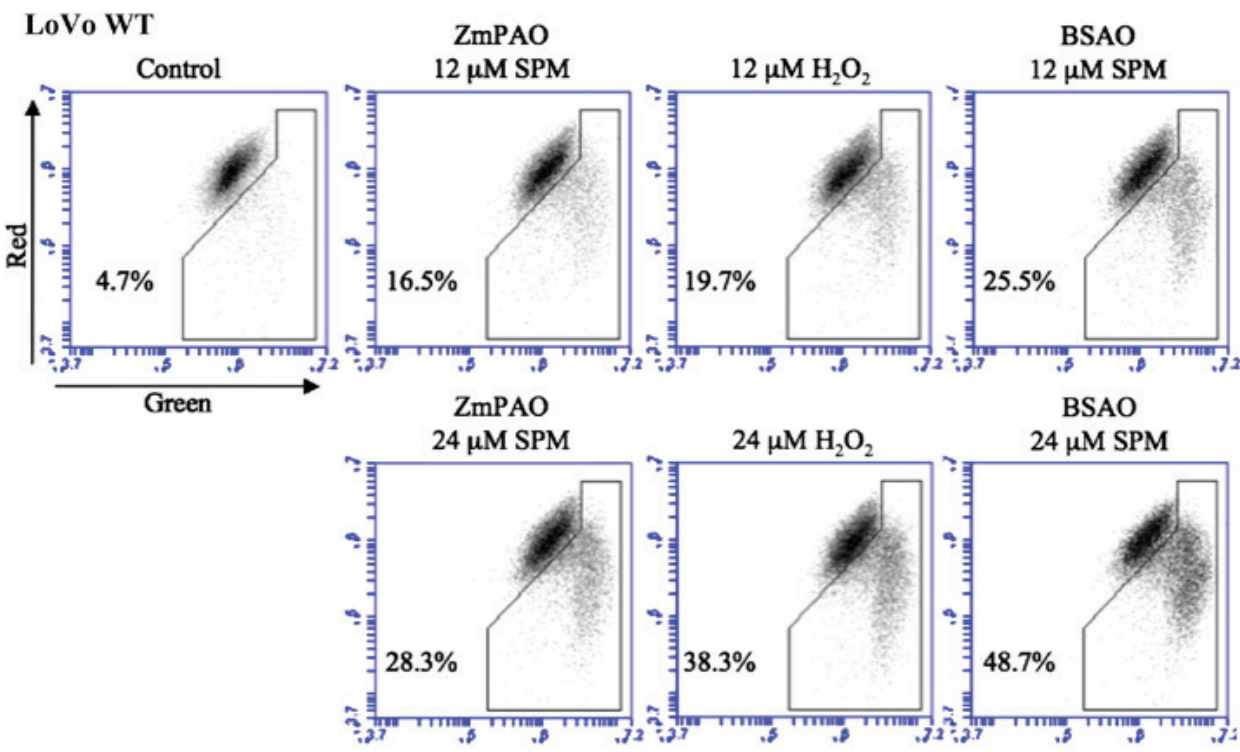

BSAO

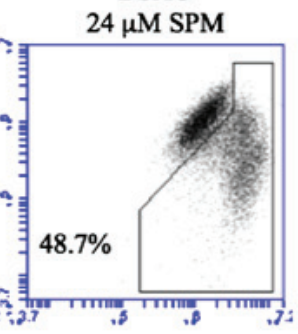

LoVo DX
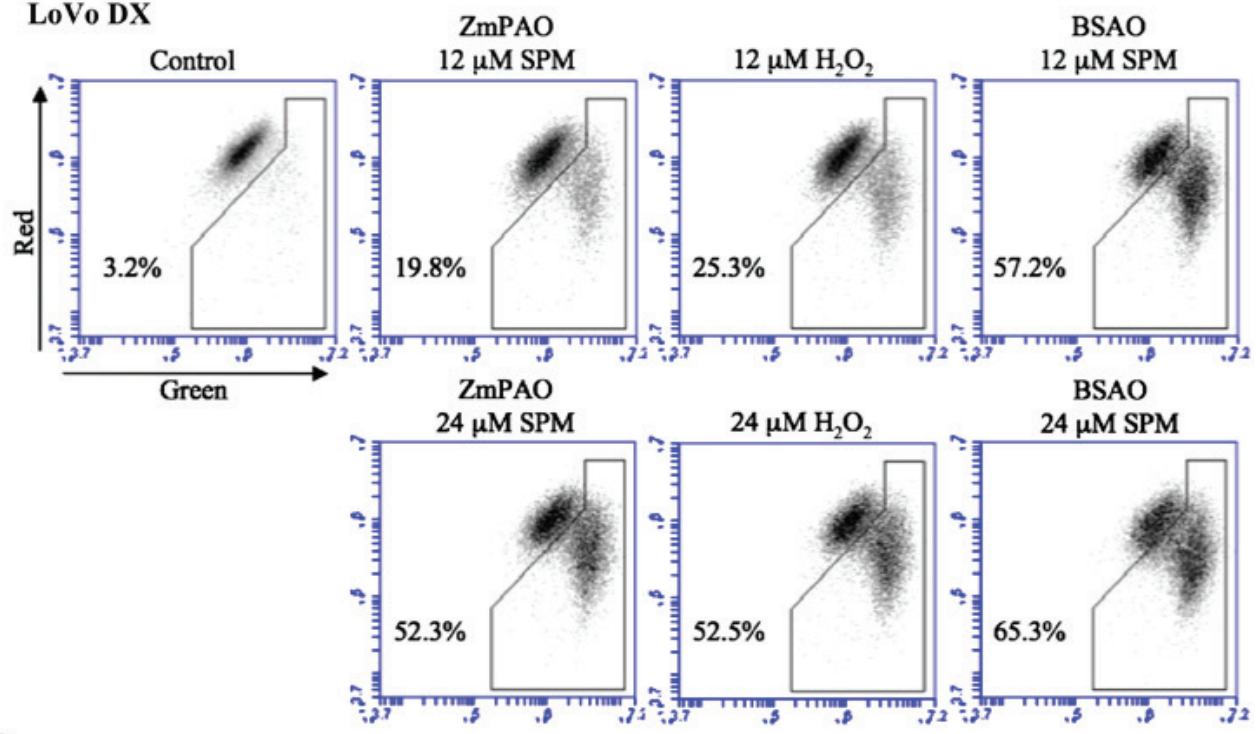

B

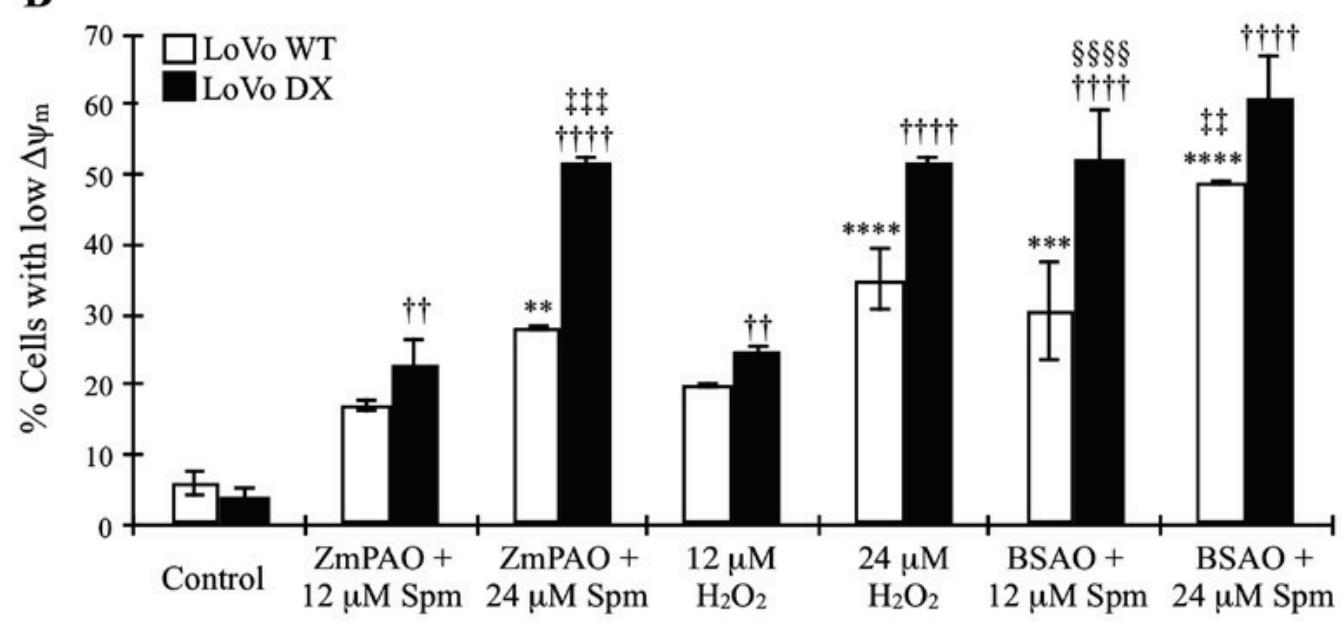

Figure 10. Effects of the treatment with ZmPAO or BSAO and spermine on mitochondrial membrane potential in LoVo cells. LoVo WT and LoVo DX cells were treated with various doses of hydrogen peroxide (positive control) or spermine in the presence of ZmPAO or BSAO for $1 \mathrm{~h}$. JC-1 fluorescent staining intensity was examined using flow cytometry. (A) Results are shown as dot plots and as the percentages of cells with an energized (top) or depolarized (bottom) mitochondrial membrane. Data are representative of 2 independent experiments with similar results. (B) Each bar represents the mean \pm SD of the cells with depolarized mitochondria of 2 independent experiments. Data were analyzed by one-way ANOVA, followed by Tukey's post hoc test. ${ }^{* *} \mathrm{P}<0.01,{ }^{* * *} \mathrm{P}<0.001$ and ${ }^{* * * * * *} \mathrm{P}<0.0001$ vs. control LoVo WT cells; ${ }^{\dagger+} \mathrm{P}<0.01$ and ${ }^{\dagger+\dagger} \mathrm{P}<0.0001$ vs. control LoVo DX cells; ${ }^{\ddagger} \mathrm{P}<0.01$ and ${ }^{+{ }_{*}} \mathrm{P}<0.001$ vs. LoVo WT cells incubated with $\mathrm{ZmPAO}$ and $24 \mu \mathrm{M}$ spermine; ${ }^{\$ \$ \$ \$} \mathrm{P}<0.0001$ vs. LoVo DX cells incubated with ZmPAO and $12 \mu \mathrm{M}$ spermine. ZmPAO, maize polyamine oxidase; BSAO, bovine serum amine oxidase; LoVo WT cells, LoVo wild-type cells; LoVo DX cells, LoVo multidrug-resistant cells. 
Cytofluorimetric analysis of mitochondrial membrane potential. To investigate the mechanisms through which the oxidative products of spermine generated by $\mathrm{ZmPAO}$ induced cell death, we examined the loss of $\Delta \psi_{\mathrm{m}}$ using a flow cytometric analysis of the control and treated cells loaded with the mitochondrial probe, JC-1. In healthy cells, membrane-permeable JC-1 dye spontaneously accumulates in the mitochondria and forms aggregates known as $\mathrm{J}$-aggregates that emit red fluorescence after excitation. By contrast, in apoptotic cells, with a low $\Delta \psi_{\mathrm{m}}$, JC-1 remains in the cytoplasm as monomers, which emit green fluorescence. Therefore, the loss of $\Delta \psi_{\mathrm{m}}$ is indicated by a decrease in the ratio of red/green fluorescence intensity. As shown in Fig. 10, in the LoVo WT and DX cells, the exposure to spermine in the presence of $\mathrm{ZmPAO}$ induced an evident mitochondrial membrane depolarization. Treatment with spermine increased the green fluorescence intensity and concomitantly decreased the red fluorescence intensity in a dose-dependent manner. The $\mathrm{ZmPAO} /$ spermine-induced $\Delta \psi_{\mathrm{m}}$ dissipation was more evident in the LoVo DX cells than in the LoVo WT ones following treatment with $24 \mu \mathrm{M}$ spermine (52.3 and $28.3 \%$, respectively). We also examined the ability of spermine with BSAO and exogenous $\mathrm{H}_{2} \mathrm{O}_{2}$ at the same concentrations to induce mitochondrial membrane depolarization in both cell lines. $\mathrm{H}_{2} \mathrm{O}_{2}$ induced a dose-dependent increase in green fluorescence at the same level or more as spermine with ZmPAO (Fig. 10). Moreover, treatment with $12 \mu \mathrm{M}$ spermine with BSAO already led to a larger increase in green fluorescence than that obtained with $\mathrm{ZmPAO}$. In the presence of $24 \mu \mathrm{M}$ spermine with $\mathrm{BSAO}$, the increase was higher in both the LoVo WT and LoVo DX cells.

\section{Discussion}

In this study, we investigated, for the first time, at least to the best of our knowledge, the potential of using polyamine oxidase $\mathrm{ZmPAO}$ as an antitumor agent in the presence of polyamines. Polyamines are degraded by polyamine oxidase, producing $\mathrm{H}_{2} \mathrm{O}_{2}$ and the corresponding aldehyde. In previous studies, it was hypothesized that these reactive metabolites, formed by $\mathrm{BSAO} /$ spermine enzymatic system, can induce cytotoxicity selectively in tumor cells, when enzymatically generated by endogenous polyamines. Moreover, the enzymes amine oxidases may further cause the depletion of polyamine levels in the tumor microenvironment in vivo, resulting in growth inhibition (39-44). Therefore, the aim of this study was to further improve our knowledge of polyamine-derived cytotoxic metabolites in inducing cell death. The study was first carried out in vitro to examine the cytotoxicity of $\mathrm{H}_{2} \mathrm{O}_{2}$ and aldehyde(s) formed by $\mathrm{ZmPAO}$-catalyzed reaction. ZmPAO, a FAD-dependent enzyme, was used due to both its higher catalytic efficiency and the lower molecular weight compared to BSAO, which are important aspects for the delivery of these enzymes into tumor cells, as a new anticancer therapy. Due to the limited success of chemotherapy for tumors, the majority of investigations have focused on the cellular and molecular mechanisms responsible for the onset of MDR $(35,39)$. Currently, resistance to drugs in tumor cells is one of the most major obstacles in the treatment of cancer. Hence, there is a demand for alternative therapeutic strategies. This study was therefore performed on LoVo human colon adenocarcinoma cells, a sensitive cell line (WT) and its MDR counterpart (DX), to examine the cytotoxic effects induced by $\mathrm{ZmPAO}$ in the presence of polyamines.

$\mathrm{ZmPAO}$ purified from the maize shoot exhibited a high affinity to spermine and spermidine and a higher specificity constant than BSAO (Table II). These features can be an advantage to sustain sufficient enzymatic activity when the enzyme is conjugated to biocompatible carrier nanoparticles. $\mathrm{ZmPAO}$ is relatively stable in storage and has the highest stability at acidic $\mathrm{pH}$ values (57). A previous study showed that the highest $\mathrm{ZmPAO}$ activity was found at $\mathrm{pH} 6.5$ for the amine substrate (45). Due to switching the energy metabolism toward glycolysis that promotes the formation of lactic acid and reduces the ability to remove tumor-derived protons by poor perfusion, it is well known that solid tumors tend to be acidic compared to normal tissues (58). The acidic conditions may thus enhance the catalytic activity of ZmPAO, particularly in the tumor microenvironment.

In this study, the effect of cell growth inhibition induced by polyamine metabolites oxidized by ZmPAO on LoVo WT and LoVo DX cells was also investigated. Since the efficacy of therapeutic agents depends on its long-term effect on cancer cells, we examined the effects of the treatments on in vitro tumorigenic capacity by employing clonogenic assay, which is widely considered to be the most valid method for the evaluation of tumor cell sensitivity to anticancer drugs. As reported above, in previous studies, it was demonstrated that $\mathrm{H}_{2} \mathrm{O}_{2}$ and aldehyde(s) derived from BSAO-catalyzed oxidation of spermine can induce cytotoxicity, greater in both LoVo DX and M14 ADR2 cancer cells than in their sensitive LoVo WT and M14 WT counterparts $(39,40)$. Consistent with previous observations, in this study, exogenous spermine and $\mathrm{ZmPAO}$ treatment reduced the number of colonies in a spermine doseand time-dependent manner in LoVo cells (Figs. 2 and 3). It was also found that treatment further decreased the viability of the LoVo DX cells when compared with that of the LoVo WT cells. Moreover, there no marked difference in cell viability was observed following treatment of both the LoVo WT and DX cells with spermine and spermidine, suggesting that the aminoaldehydes, $N$-(3-aminopropyl)-4-aminobutanal and 4-aminobutanal, derived from spermine and spermidine, respectively (Fig. 1), do not exert any cytotoxic effect. This effect was mainly due to $\mathrm{H}_{2} \mathrm{O}_{2}$. Similar results were also obtained with the AGS cells (data not shown), indicating that the effect of cell growth inhibition induced by polyamines and ZmPAO was not cell-specific.

Further colony formation assay revealed that cytotoxicity induced by spermine metabolites in both the LoVo WT and DX cells was completely prevented by the addition of exogenous catalase, an enzyme that decomposes $\mathrm{H}_{2} \mathrm{O}_{2}$, while it was not affected by the presence of exogenous $\mathrm{NAD}^{+}$-dependent ALDH, an enzyme that oxidizes aldehydes to the corresponding carboxylic acids (Fig. 3). This result supports the hypothesis that $\mathrm{H}_{2} \mathrm{O}_{2}$ is mainly responsible for the cytotoxicity. The addition of catalase also protected the AGS cells from oxidative products of spermine and spermidine catalyzed by ZmPAO (data not shown).

Unexpectedly, a slightly higher cytotoxicity was observed when both the LoVo WT and DX cell were treated with exogenous $\mathrm{H}_{2} \mathrm{O}_{2}$ than with the same concentration 
of spermine in the presence of ZmPAO (Fig. 4). Although $\mathrm{ZmPAO}$ theoretically produces one molecule of $\mathrm{H}_{2} \mathrm{O}_{2}$ from spermine, in addition to $\mathrm{N}$-(3-aminopropyl)-4-aminobutanal and 1,3-diaminopropane, the stoichiometric amount of $\mathrm{H}_{2} \mathrm{O}_{2}$ actually generated by $\mathrm{ZmPAO} /$ spermine enzymatic reaction might be lower than that of exogenous $\mathrm{H}_{2} \mathrm{O}_{2}$ when directly exposed, as reported in a previous study for BSAO (59).

In this study, a clonogenic assay also revealed that the cytotoxicity induced by ZmPAO and spermine was less than that caused by BSAO and spermine (Fig. 5). The greater cytotoxicity induced by BSAO was probably due to the presence of acrolein, another toxic metabolite only formed by the BSAO/spermine enzymatic system (28).

For clinical applications, the increase in the efficiency of the in situ generation of polyamine metabolites is fundamental. Several studies have demonstrated that an increase in the incubation temperature from 37 to $42^{\circ} \mathrm{C}$ enhances the cytotoxicity in both LoVo and M14 cells exposed to BSAO and spermine; the cytotoxic effect has been shown to be higher in both MDR cell lines than in their drug-sensitive counterparts $(40,60,61)$. Other studies have demonstrated that pre-treatment of the cells with MDL 72527, a lysosomotropic compound, sensitizes several tumor cell lines to the subsequent exposure to BSAO and spermine $(40,41,62)$. In addition, chloroquine, another lysosomotropic agent, was recently reported to enhance apoptotic and non-apoptotic cell death induced by $\mathrm{H}_{2} \mathrm{O}_{2}$ and other spermine metabolites in M14 cells, particularly in ADR2 cells $(42,63)$. It has also been observed that the ectopic expression of recombinant $\mathrm{ZmPAO}$ in the nucleus of MCF-7 human breast cancer cells confers a greater growth sensitivity to etoposide, a potent DNA topoisomerase II inhibitor widely used for cancer therapy (64), suggesting that ZmPAO may also be a potential tool which may be used to enhance efficacy of anti-proliferative agents. Therefore, a further investigation of drug combinations with the aim of enhancing the induction of cell death by polyamine metabolites appears to be necessary.

In this study, Annexin V-FITC and PI staining assay revealed that treatment with spermine and $\mathrm{ZmPAO}$ increased the percentage of apoptotic cells in a spermine dose-dependent manner, and the proportion of apoptotic cells was significantly higher in the LoVo DX cells than the LoVo WT ones (Fig. 6), indicating that treatment with spermine and $\mathrm{ZmPAO}$ is able to induce cell death through apoptosis. The apoptotic process was also detectable in the AGS cells (data not shown). During the initial phases of apoptosis, cell shrinkage and the membrane remains intact, resulting in a decrease in forward light scatter and an increase in side light scatter determined by flow cytometry. In this study, apoptotic cells were detected and distinguished from necrosis on the basis of the scatter parameters following treatment with ZmPAO and spermine on both cell lines (data not shown). The nature of apoptotic cell death was also demonstrated by the increase in the sub-G1 hypodiploid cell population (Fig. 7).

In this study, SEM and TEM observations also confirmed the occurrence of apoptosis in the cancer cells following treatment with the enzymatic system (Figs. 8 and 9). Spermine metabolites catalyzed by ZmPAO induced morphological alterations, such as plasma membrane blebbing, particularly in the LoVo DX cells treated with $18 \mu \mathrm{M}$ spermine. Intense mitochondrial changes in the cells treated with $21 \mu \mathrm{M}$ spermine and $\mathrm{ZmPAO}$ were also observed. The morphological and ultrastructural changes observed are the typical features of apoptosis. The advantage of the apoptotic process over necrosis is that it does not induce the inflammatory response and immunoreaction after cell death. Apoptotic cells are removed through phagocytosis by neighboring cells and macrophages without releasing their contents that can cause damage to the surrounding tissues. Indeed, the majority of cytotoxic drugs in current clinical applications have been shown to induce the apoptosis of cancer cells. Therefore, the induction of apoptosis by spermine metabolites may be considered as one of the future therapeutic strategies for cancer therapy.

It is known that the mitochondria play a pivotal role in the intrinsic apoptotic pathway and a reduction in $\Delta \psi_{\mathrm{m}}$ is an early irreversible step (65). The observations reported in this study indicated that spermine metabolite-induced apoptosis was preceded by the $\Delta \psi_{\mathrm{m}}$ collapse in the LoVo cells (Fig. 10). $\mathrm{H}_{2} \mathrm{O}_{2}$ generated by the oxidation of spermine is able to cross the cell membrane and the inner membrane of mitochondria and directly interacts with endogenous molecules and structures, inducing an intense oxidative stress under appropriate conditions $(40,61)$. It is considered that oxidative stress is involved in the induction of mitochondrial permeability transition by opening the transition pore, leading to a loss of $\Delta \psi_{\mathrm{m}}$, mitochondrial swelling and to the rupture of the outer membrane. It has been previously demonstrated that treatment with $12 \mu \mathrm{M}$ exogenous $\mathrm{H}_{2} \mathrm{O}_{2}$ induced an increase in the mRNA levels of the BAX pro-apoptotic gene in LoVo DX cells, while the pro-survival Bcl-2 gene did not reveal any variation in expression following treatment (66). In order to further obtain information on the key molecular changes following exposure to polyamine metabolites, a quantitative proteomic approach with Stable-Isotope Labeling by Amino acids in cell culture (SILAC) on tumor cells is promising and ongoing (unpublished data).

The higher sensitivity to cytotoxic spermine metabolites of LoVo DX cells as compared with their drug-sensitive cells has previously been attributed to a higher basal production of ROS, although the ROS levels were not related to the glutathione-dependent $\mathrm{H}_{2} \mathrm{O}_{2}$ metabolism because both cells have the same glutathione levels $(38,39)$. When LoVo DX cells are treated with polyamine metabolites, they may be no longer able to eliminate additional ROS by the cellular antioxidant system, leading to an earlier and greater loss of mitochondrial functionality than LoVo WT cells. Higher levels of ROS in LoVo DX cells than LoVo WT may be due to mitochondrial electron transport chain activity as LoVo DX cells exhibit P-gp overexpression that requires a higher ATP production. It is known that there are differences in mitochondrial electron transport chain activity between sensitive and resistant cell lines (39). A high activity of respiratory complex protein subunits can induce a continuous and physiological production of superoxide radical, $\mathrm{H}_{2} \mathrm{O}_{2}$ and hydroxyl radical.

Whether the concentration of polyamine metabolites is sufficient to induce cytotoxicity is unclear. The results reported in this study demonstrated that at least $12 \mu \mathrm{M}$ of spermine in the presence of ZmPAO significantly reduced the viability of both the LoVo WT and LoVo DX cells. However, although polyamine concentrations are upregulated in tumors, free polyamines 
which can be oxidized by ZmPAO are present only in small amounts as polyamines preferentially bind to macromolecules, such as DNA, RNA, and proteins (12). Moreover, slow and low ROS production may be completely removed by enzymes of the antioxidant system, such as catalase, glutathione peroxidase, and superoxide dismutase (65). A recent study demonstrated that recombinant $\mathrm{ZmPAO}$ overexpression in human breast cancer cells did not inhibit cell growth under normal growth conditions (64). Nevertheless, the overexpression sensitized the cells to etoposide as described above. The antitumor potential of BSAO has also been demonstrated in vivo in a mouse melanoma model $(43,44)$. In the development of novel treatment strategies against tumors, their side-effects against normal cells should be considered. Therefore, it was previously shown that normal human epidermal melanocytes displayed a higher resistance than M14 cells against $\mathrm{BSAO/spermine-induced} \mathrm{cytotoxicity} \mathrm{(42).} \mathrm{A} \mathrm{further} \mathrm{research}$ is directed at examining the differences between primary cells (neurons) and neuroblastoma cancer cells in their sensitivity to treatment with polyamine metabolites (unpublished data).

It would of interest to determine the intracellular polyamine levels following treatment with $\mathrm{ZmPAO}$ in vivo. Thus far, for the in vitro assay performed in this study, we used exogenous spermine to observe cytotoxicity, although in vivo, this enzymatic system is able to deaminate endogenous polyamines. Since polyamine levels are high even in the tumor microenvironment, extracellular polyamines to induce cytotoxicity could also be used. However, ZmPAO-overexpressing MCF7 cells have shown only a small, not statistically significant, decrease in the levels of spermine and spermidine when compared with control cells (64). However, the depletion of polyamines in the tumor microenvironment may be able to affect polyamine uptake and its distribution.

In conclusion, this study demonstrated that treatment with $\mathrm{ZmPAO}$ and spermine induced cell death through an apoptotic mechanism in human LoVo cancer cells. Microscopy analysis also revealed that the treatment caused characteristic morphological and ultrastructural changes associated with apoptosis. Furthermore, the cytotoxicity was significantly greater in the LoVo DX cells than the LoVo WT cells. Therefore, all findings obtained in this study suggest that polyamine oxidation by ZmPAO, specifically in tumor microenvironment, may be taken into account for a future anticancer therapy, rendering this approach attractive in combating cancer and mainly in treating MDR cancer patients.

\section{Acknowledgements}

The authors would like to thank the 'International Polyamine Foundation - ONLUS' for the availability to look up the polyamines documentation.

\section{Funding}

This study was funded by the generous support of 'La Sapienza' University of Rome and Italian MIUR (Ministero dell'Istruzione, dell'Università e della Ricerca), AIRC IG 17575, IG 20801; Istituto Pasteur - Fondazione Cenci-Bolognetti, AFM-Telethon grant \#21025. E.A. thanks Wakunaga Pharmaceutical Co. Ltd.
(Japan) for the scholarship given to $\mathrm{SO}$ for supporting his $\mathrm{PhD}$ research work.

\section{Availability of data and materials}

All data generated or analyzed during this study are included in this published article or are available from the corresponding author on reasonable request.

\section{Authors' contributions}

EA and DAS conceived this study and coordinated the collaboration among the authors. SO, RM, SM and AC performed all the experiments on the LoVo and AGS cells. GC, RA and EG optimized the protocols for the analyses and PAO/BSAO purification. All authors wrote the manuscript and all authors have read and approved the final manuscript.

\section{Ethics approval and consent to participate}

Not applicable.

\section{Patient consent for publication}

Not applicable.

\section{Competing interests}

DAS is the Editor-in-Chief for the journal, but had no personal involvement in the reviewing process, or any influence in terms of adjudicating on the final decision, for this article. The other authors declare that they have no competing interests.

\section{References}

1. Pegg AE: Polyamine metabolism and its importance in neoplastic growth and a target for chemotherapy. Cancer Res 48: 759-774, 1988.

2. Bachrach U, Wang YC and Tabib A: Polyamines: New cues in cellular signal transduction. News Physiol Sci 16: 106-109, 2001.

3. Mattoo AK, Minocha SC, Minocha R and Handa AK: Polyamines and cellular metabolism in plants: Transgenic approaches reveal different responses to diamine putrescine versus higher polyamines spermidine and spermine. Amino Acids 38: 405-413, 2010.

4. Migliaccio N, Martucci NM, Ruggiero I, Sanges C, Ohkubo S, Lamberti A, Agostinelli E and Arcari P: Ser/Thr kinases and polyamines in the regulation of non-canonical functions of elongation factor 1A. Amino Acids 48: 2339-2352, 2016.

5. Schuber F: Influence of polyamines on membrane functions. Biochem J 260: 1-10, 1989.

6. Ficker E, Taglialatela M, Wible BA, Henley CM and Brown AM: Spermine and spermidine as gating molecules for inward rectifier $\mathrm{K}^{+}$channels. Science 266: 1068-1072, 1994.

7. Neel BG and Tonks NK: Protein tyrosine phosphatases in signal transduction. Curr Opin Cell Biol 9: 193-204, 1997.

8. Grancara S, Dalla Via L, García-Argáez AN, Ohkubo S, Pacella E, Manente S, Bragadin M, Toninello A and Agostinelli E: Spermine cycling in mitochondria is mediated by adenine nucleotide translocase activity: Mechanism and pathophysiological implications. Amino Acids 48: 2327-2337, 2016.

9. Madeo F, Eisenberg T, Pietrocola F and Kroemer G: Spermidine in health and disease. Science 359: eaan2788, 2018.

10. Lee CY, Su GC, Huang WY, Ko MY, Yeh HY, Chang GD, Lin SJ and Chi P: Promotion of homology-directed DNA repair by polyamines. Nat Commun 10: 65, 2019. 
11. Cervelli M, Angelucci E, Germani F, Amendola R and Mariottini P: Inflammation, carcinogenesis and neurodegeneration studies in transgenic animal models for polyamine research. Amino Acids 46: 521-530, 2014

12. Park MH and Igarashi K: Polyamines and their metabolites as diagnostic markers of human diseases. Biomol Ther (Seoul) 21 $1-9,2013$.

13. Wallace HM and Fraser AV: Inhibitors of polyamine metabolism: Review article. Amino Acids 26: 353-365, 2004.

14. McCann PP and Pegg AE: Ornithine decarboxylase as an enzyme target for therapy. Pharmacol Ther 54: 195-215, 1992.

15. Nakanishi $\mathrm{S}$ and Cleveland JL: Targeting the polyaminehypusine circuit for the prevention and treatment of cancer. Amino Acids 48: 2353-2362, 2016

16. Tabib A and Bachrach U: Role of polyamines in mediating malignant transformation and oncogene expression. Int J Biochem Cell Biol 31: 1289-1295, 1999.

17. Patel AR and Wang JY: Polyamines modulate transcription but not posttranscription of c-myc and c-jun in IEC-6 cells. Am J Physiol 273: C1020-C1029, 1997.

18. Xiao L and Wang JY: Posttranscriptional regulation of gene expression in epithelial cells by polyamines. Methods Mol Biol 720: 67-79, 2011

19. Šebela M, Radová A, Angelini R, Tavladoraki P, Frébort I and Peč P: FAD-containing polyamine oxidases: A timely challenge for researchers in biochemistry and physiology of plants. Plant Sci 160: 197-207, 2001

20. Suzuki Y and Yanagisawa H: Purification and properties of maize polyamine oxidase: A flavoprotein. Plant Cell Physiol 21: 1085-1094, 1980.

21. Cona A, Moreno S, Cenci F, Federico R and Angelini R: Cellular re-distribution of flavin-containing polyamine oxidase in differentiating root and mesocotyl of Zea mays L. seedlings. Planta 221: 265-276, 2005.

22. Cona A, Cenci F, Cervelli M, Federico R, Mariottini P, Moreno S and Angelini R: Polyamine oxidase, a hydrogen peroxideproducing enzyme, is up-regulated by light and down-regulated by auxin in the outer tissues of the maize mesocotyl. Plant Physiol 131: 803-813, 2003.

23. Pennell RI and Lamb C: Programmed cell death in plants. Plant Cell 9: 1157-1168, 1997.

24. Kärkönen A and Kuchitsu K: Reactive oxygen species in cell wall metabolism and development in plants. Phytochemistry 112: 22-32, 2015

25. Houen G, Struve C, Søndergaard R, Friis T, Anthoni U, Nielsen PH, Christophersen C, Petersen BO and Duus JØ Substrate specificity of the bovine serum amine oxidase and in situ characterisation of aminoaldehydes by NMR spectroscopy. Bioorg Med Chem 13: 3783-3796, 2005.

26. De Matteis G, Agostinelli E, Mondovì B and Morpurgo L: The metal function in the reactions of bovine serum amine oxidase with substrates and hydrazine inhibitors. J Biol Inorg Chem 4: 348-353, 1999.

27. Agostinelli E and Seiler N: Non-irradiation-derived reactive oxygen species (ROS) and cancer: Therapeutic implications. Amino Acids 31: 341-355, 2006.

28. Sharmin S, Sakata K, Kashiwagi K, Ueda S, Iwasaki S, Shirahata A and Igarashi K: Polyamine cytotoxicity in the presence of bovine serum amine oxidase. Biochem Biophys Res Commun 282: 228-235, 2001.

29. Binda C, Coda A, Angelini R, Federico R, Ascenzi P and Mattevi A: A 30-angstrom-long U-shaped catalytic tunnel in the crystal structure of polyamine oxidase. Structure 7: 265-276, 1999.

30. Tavladoraki P, Cona A and Angelini R: Copper-containing amine oxidases and FAD-dependent polyamine oxidases are key players in plant tissue differentiation and organ development. Front Plant Sci 7: 824-834, 2016. Review.

31. Cona A, Federico R, Gramiccia M, Orsini S and Gradoni L: The amino aldehydes produced by spermine and spermidine oxidation with maize polyamine oxidase have anti-leishmanial effect. Biotechnol Appl Biochem 14: 54-59, 1991.

32. Cona A, Rea G, Angelini R, Federico R and Tavladoraki P: Functions of amine oxidases in plant development and defence. Trends Plant Sci 11: 80-88, 2006.

33. Bouchereau A, Aziz A, Larher F and Martin-Tanguy J: Polyamines and environmental challenges: Recent development. Plant Sci 140: 103-125, 1999

34. Massa S, Spanò D, Pintus F, Medda R and Floris G: Oxidation of di- and polyamines: In vitro effect of amino aldehydes on the vitality of Leishmania promastigotes. Med Chem Res 19: 77-83, 2010.
35. Wu Q, Yang Z, Nie Y, Shi Y and Fan D: Multi-drug resistance in cancer chemotherapeutics: Mechanisms and lab approaches. Cancer Lett 347: 159-166, 2014.

36. Cole SP: Targeting multidrug resistance protein 1 (MRP1, ABCC1): Past, present, and future. Annu Rev Pharmacol Toxicol 54: 95-117, 2014.

37. Meschini S, Calcabrini A, Monti E, Del Bufalo D, Stringaro A, Dolfini E and Arancia G: Intracellular P-glycoprotein expression is associated with the intrinsic multidrug resistance phenotype in human colon adenocarcinoma cells. Int J Cancer 87: 615-628, 2000.

38. Arancia G, Calcabrini A, Marra M, Crateri P, Artico M, Martone A, Martelli F and Agostinelli E: Mitochondrial alterations induced by serum amine oxidase and spermine on human multidrug resistant tumor cells. Amino Acids 26: 273-282, 2004

39. Calcabrini A, Arancia G, Marra M, Crateri P, Befani O, Martone A and Agostinelli E: Enzymatic oxidation products of spermine induce greater cytotoxic effects on human multidrugresistant colon carcinoma cells ( $\mathrm{LoV}$ ) than on their wild-type counterparts. Int J Cancer 99: 43-52, 2002.

40. Agostinelli E, Belli F, Molinari A, Condello M, Palmigiani P, Vedova LD, Marra M, Seiler N and Arancia G: Toxicity of enzymatic oxidation products of spermine to human melanoma cells (M14): Sensitization by heat and MDL 72527. Biochim Biophys Acta 1763: 1040-1050, 2006.

41. Agostinelli E, Condello M, Molinari A, Tempera G, Viceconte N and Arancia G: Cytotoxicity of spermine oxidation products to multidrug resistant melanoma M14 ADR2 cells: Sensitization by the MDL 72527 lysosomotropic compound. Int J Oncol 35: 485-498, 2009

42. Agostinelli E, Condello M, Tempera G, Macone A, Bozzuto G, Ohkubo S, Calcabrini A, Arancia G and Molinari A: The combined treatment with chloroquine and the enzymatic oxidation products of spermine overcomes multidrug resistance of melanoma M14 ADR2 cells: A new therapeutic approach. Int J Oncol 45: 1109-1122, 2014.

43. Averill-Bates DA, Chérif A, Agostinelli E, Tanel A and Fortier G: Anti-tumoral effect of native and immobilized bovine serum amine oxidase in a mouse melanoma model. Biochem Pharmacol 69: 1693-1704, 2005.

44. Averill-Bates DA, Ke Q, Tanel A, Roy J, Fortier G and Agostinelli E: Mechanism of cell death induced by spermine and amine oxidase in mouse melanoma cells. Int J Oncol 32: 79-88, 2008.

45. Polticelli F, Basran J, Faso C, Cona A, Minervini G, Angelini R, Federico R, Scrutton NS and Tavladoraki P: Lys300 plays a major role in the catalytic mechanism of maize polyamine oxidase. Biochemistry 44: 16108-16120, 2005.

46. Averill-Bates DA, Agostinelli E, Przybytkowski E, Mateescu MA and Mondovì B: Cytotoxicity and kinetic analysis of purified bovine serum amine oxidase in the presence of spermine in Chinese hamster ovary cells. Arch Biochem Biophys 300: 75-79, 1993.

47. Agostinelli E, De Matteis G, Mondovì B and Morpurgo L: Reconstitution of $\mathrm{Cu}^{2+}$-depleted bovine serum amine oxidase with $\mathrm{Co}^{2+}$. Biochem J 330: 383-387, 1998.

48. Cervelli M, Cona A, Angelini R, Polticelli F, Federico R and Mariottini P: A barley polyamine oxidase isoform with distinct structural features and subcellular localization. Eur J Biochem 268: 3816-3830, 2001

49. Federico R, Alisi C and Forlani F: Properties of the polyamine oxidase from the cell wall of maize seedlings. Phytochemistry 28 : 45-46, 1989.

50. Turini P, Sabatini S, Befani O, Chimenti F, Casanova C, Riccio PL and Mondovì B: Purification of bovine plasma amine oxidase. Anal Biochem 125: 294-298, 1982.

51. Janes SM, Mu D, Wemmer D, Smith AJ, Kaur S, Maltby D, Burlingame AL and Klinman JP: A new redox cofactor in eukaryotic enzymes: 6-hydroxydopa at the active site of bovine serum amine oxidase. Science 248: 981-987, 1990

52. Angelini R, Cona A and Tavladoraki P: Determination of copper amine oxidase activity in plant tissues. Methods Mol Biol 1694: 129-139, 2018.

53. Dolfini E, Dasdia T, Arancia G, Molinari A, Calcabrini A, Scheper RJ, Flens MJ, Gariboldi MB and Monti E: Characterization of a clonal human colon adenocarcinoma line intrinsically resistant to doxorubicin. Br J Cancer 76: 67-76, 1997.

54. Grandi M, Geroni C and Giuliani FC: Isolation and characterization of a human colon adenocarcinoma cell line resistant to doxorubicin. Br J Cancer 54: 515-518, 1986. 
55. van Engeland M, Nieland LJ, Ramaekers FC, Schutte B and Reutelingsperger CP: Annexin V-affinity assay: A review on an apoptosis detection system based on phosphatidylserine exposure. Cytometry 31: 1-9, 1998.

56. Nicoletti I, Migliorati G, Pagliacci MC, Grignani F and Riccardi C: A rapid and simple method for measuring thymocyte apoptosis by propidium iodide staining and flow cytometry. J Immunol Methods 139: 271-279, 1991.

57. Federico R, Cona $\mathrm{A}$, Angelini R, Schininà $\mathrm{ME}$ and Giartosio $\mathrm{A}$ Characterization of maize polyamine oxidase. Phytochemistry 29: 2411-2414, 1990.

58. Damaghi M, Wojtkowiak JW and Gillies RJ: $\mathrm{pH}$ sensing and regulation in cancer. Front Physiol 4: 370-379, 2013.

59. De Biase D, Agostinelli E, De Matteis G, Mondovì B and Morpurgo L: Half-of-the-sites reactivity of bovine serum amine oxidase. Reactivity and chemical identity of the second site. Eur J Biochem 237: 93-99, 1996.

60. Agostinelli E, Arancia G, Vedova LD, Belli F, Marra M, Salvi $\mathrm{M}$ and Toninello A: The biological functions of polyamine oxidation products by amine oxidases: Perspectives of clinical applications. Amino Acids 27: 347-358, 2004.

61. Agostinelli E, Belli F, Dalla Vedova L, Marra M, Crateri P and Arancia G: Hyperthermia enhances cytotoxicity of amine oxidase and spermine on drug-resistant LoVo colon adenocarcinoma cells. Int J Oncol 28: 1543-1553, 2006.

62. Agostinelli E, Vedova LD, Belli F, Condello M, Arancia G and Seiler N: Sensitization of human colon adenocarcinoma cells (LoVo) to reactive oxygen species by a lysosomotropic compound. Int J Oncol 29: 947-955, 2006.
63. Iyamu E, Perdew H and Woods G: Growth inhibitory and differentiation effects of chloroquine and its analogue on human leukemic cells potentiate fetal hemoglobin production by targeting the polyamine pathway. Biochem Pharmacol 77: 1021-1028, 2009.

64. Marcocci L, Casadei M, Faso C, Antoccia A, Stano P, Leone S, Mondovì B, Federico R and Tavladoraki P: Inducible expression of maize polyamine oxidase in the nucleus of MCF-7 human breast cancer cells confers sensitivity to etoposide. Amino Acids 34: 403-412, 2008.

65. Grancara S, Zonta F, Ohkubo S, Brunati AM, Agostinelli E and Toninello A: Pathophysiological implications of mitochondrial oxidative stress mediated by mitochondriotropic agents and polyamines: The role of tyrosine phosphorylation. Amino Acids 47: 869-883, 2015.

66. Amendola R, Cervelli M, Fratini E, Sallustio DE, Tempera G, Ueshima T, Mariottini P and Agostinelli E: Reactive oxygen species spermine metabolites generated from amine oxidases and radiation represent a therapeutic gain in cancer treatments. Int J Oncol 43: 813-820, 2013.

This work is licensed under a Creative Commons Attribution-NonCommercial-NoDerivatives 4.0 International (CC BY-NC-ND 4.0) License. 